\title{
Review \\ Plant E3 Ligases and Their Role in Abiotic Stress Response
}

\author{
Raed Al-Saharin ${ }^{1, *}$, Hanjo Hellmann ${ }^{2} \oplus$ and Sutton Mooney ${ }^{2}$ \\ 1 Department of Applied Biology, Tafila Technical University, At-Tafilah 66110, Jordan \\ 2 School of Biological Sciences, Washington State University, Pullman, WA 99163, USA; \\ hellmann@wsu.edu (H.H.); suttonmooney@wsu.edu (S.M.) \\ * Correspondence: raed.alsaharin@ttu.edu.jo
}

check for

updates

Citation: Al-Saharin, R.; Hellmann, H.; Mooney, S. Plant E3 Ligases and Their Role in Abiotic Stress Response. Cells 2022, 11, 890. https://doi.org/ $10.3390 /$ cells 11050890

Academic Editor: Marian Brestic

Received: 13 December 2021

Accepted: 2 March 2022

Published: 4 March 2022

Publisher's Note: MDPI stays neutral with regard to jurisdictional claims in published maps and institutional affiliations.

Copyright: (C) 2022 by the authors. Licensee MDPI, Basel, Switzerland. This article is an open access article distributed under the terms and conditions of the Creative Commons Attribution (CC BY) license (https:// creativecommons.org/licenses/by/ $4.0 /)$.

\begin{abstract}
Plants, as sessile organisms, have limited means to cope with environmental changes. Consequently, they have developed complex regulatory systems to ameliorate abiotic stresses imposed by environmental changes. One such system is the ubiquitin proteasome pathway, which utilizes E3 ligases to target proteins for proteolytic degradation via the $26 \mathrm{~S}$ proteasome. Plants ex-press a plethora of E3 ligases that are categorized into four major groups depending on their structure. They are involved in many biological and developmental processes in plants, such as DNA repair, photomorphogenesis, phytohormones signaling, and biotic stress. Moreover, many E3 ligase targets are proteins involved in abiotic stress responses, such as salt, drought, heat, and cold. In this review, we will provide a comprehensive overview of E3 ligases and their substrates that have been connected with abiotic stress in order to illustrate the diversity and complexity of how this pathway enables plant survival under stress conditions.
\end{abstract}

Keywords: E3 ligase; abiotic stress; drought stress; salt stress; oxidative stress; temperature stress; heavy metal stress

\section{Introduction}

Worldwide agricultural production has been and continues to experience severe yield losses due to exposure to abiotic stress conditions, such as drought, salt, or heat. It has been shown in a recent study that $50 \%$ of worldwide crop production is lost as a result of abiotic stresses in which temperature, drought, and salt stresses contribute to more than $90 \%$ of such loss [1]. Moreover, the worldwide cost of climate change for crops is estimated to rise up to $\$ 80$ billion at $2{ }^{\circ} \mathrm{C}$ warming per year [2].

Abiotic stress is essentially any environmental condition that negatively affects the growth and general development of a plant [3]. This may range from mechanical disturbances, such as strong winds, to rapid changes in light conditions on a cloudy day, but generally it is mostly connected with severe stress conditions, such as soil salinity, heat waves, and drought stress [3-5]. The sessile lifestyle of plants makes it impossible for them to avoid these stressors by simply changing their location; hence, they need to have strategies in place to rapidly respond to changes in their environment in order to survive and sustain their growth.

An example that allows plants to respond to a very broad range of different stressors within minutes is represented by the ubiquitin proteasome pathway (UPP) [6]. The UPP is highly conserved among eukaryotes and mechanically comprises four basic steps (Figure 1). The first step is an ATP-dependent activation of ubiquitin (UBQ) by an E1 enzyme. The E1 binds the UBQ and transfers it in a second step to an UBQ-conjugating E2 enzyme. In the third step the E2 physically associates with an E3 UBQ ligase that has recruited a substrate protein to facilitate its ubiquitylation. Classically, build-up of a UBQ chain on the substrate marks the protein for the final step, which is degradation by the $26 \mathrm{~S}$ proteasome (Figure 1) [7]. 


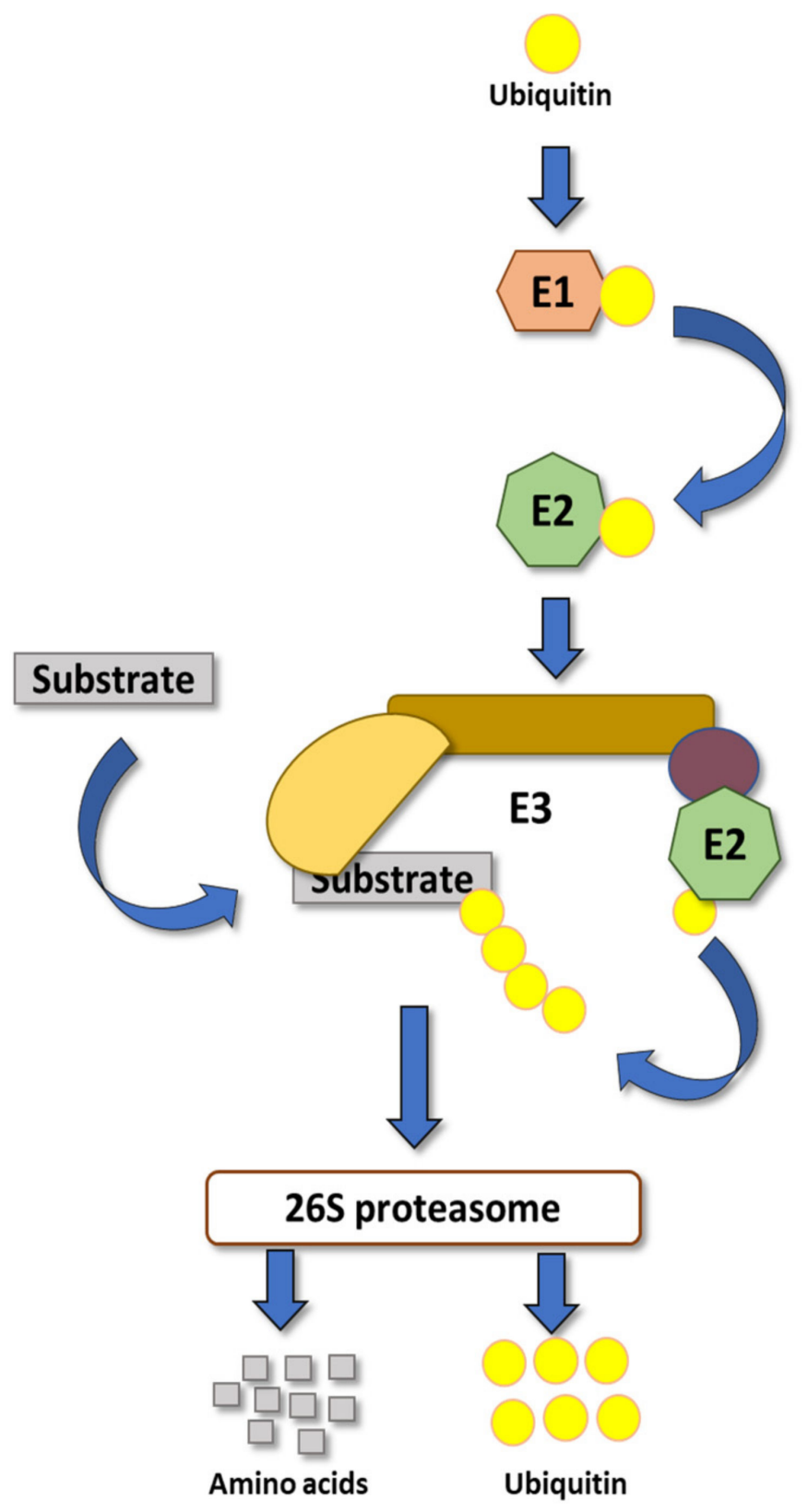

Figure 1. The ubiquitin proteasome pathway. Ubiquitin binds to E1, and E1 transfers the ubiquitin to E2, which binds with E3. E3 facilitates the transfer of ubiquitin from E2 to the substrate. Once the substrate is polyubiquitinated, it becomes a target for $26 \mathrm{~S}$ proteasome for subsequent degradation.

Plant genomes encode only a few E1 and E2 enzymes, while they have an abundance of E3s. For example, Arabidopsis thaliana and rice (Oryza sativa) have two and six E1s [8,9], respectively, 37 and 39 E2s [10,11], but more than 1100 predicted E3s [12,13]. Plant E3s can be classified into four major families based on their specific domains and complex formation: U-box, Homology to the E6-associated protein C-terminus (HECT) E3s, and really interesting new gene (RING)-finger, which are classified as either monomeric or multimeric E3 ligases [6].

The most diverse group within these E3s are multimeric E3 ligases that contain a cullin as their central scaffolding subunit. Here, the cullin interacts at its $\mathrm{C}$-terminal region to a RING-finger domain containing protein [14]. The RING finger is a Zinc-binding domain that also facilitates E2 attachment [15]. The N-terminal region of the cullin interacts with substrate receptors that bring proteins into proximity with the cullin-bound E2 for 
ubiquitylation [16]. Four different cullin-based E3s have been described in plants. First, Skip1-Cullin1-F-box (SCF) complexes use proteins as substrate adaptors that contain an Fbox motif $[17,18]$. SCF complexes have been widely described in context with development, light and phytohormone signaling, mitotic processes, and abiotic stress [14,19-28]. This wide range of SCF functions is not surprising since some plants can encode for more than 1000 F-box proteins [29,30]. Second, Cullin3-RING E3 ligases (CRL3) use proteins as substrate adaptors that contain a Broad-complex, Tramtrack, and Bric-à-brac/POxvirus and Zinc finger $(\mathrm{BTB} / \mathrm{POZ})$ domain [31,32]. BTB/POZ proteins are less abundant than F-box proteins, but can also vary between 80 to 100+ in plants [33-35]. CRL3s have been implicated with abiotic and biotic stress responses, as well as blue and red light signaling, flowering time, and metabolic processes [31,32,36-43]. Third, Cullin4 RING E3 ligases (CRL4) use proteins with a modified WD40 domain as substrate adaptors [44], and these adaptors number in the range of 100 in plants [45,46]. This class of E3 ligases is known for DNA damage and abiotic stress responses, as well as photomorphogenesis [47-49]. Finally, the Anaphase Promoting Complex/Cyclosome (APC/C) is required for sister chromatid separation in anaphase, and DNA replication processes in S-phase, but it also has been brought into context with auxin signaling [50,51].

Monomeric RING E3s facilitate substrate and E2 binding as a single moiety. They are highly diverse, and plants often encode for more than 400-500 different members [52]. Due to this diversity, they have been described in various developmental plant processes, but are also often involved in abiotic and biotic stress responses [6].

U-box E3s contain a modified RING finger domain that lacks the Zinc binding, but is still able to recruit E2s [53]. These E3 ligases also function as monomeric E3s and encompass less than 100 members in plants [54-57]. They function widely in abiotic and biotic stress responses, but have also been described, for example, in apical meristem maintenance or phytohormone signaling [58-67].

Finally, HECT domain E3s comprise the group with the fewest members in a given plant species, normally less than 20 [68-70]. They are monomeric E3s as well, and they have a distinct mechanism of ubiquitylation because they indirectly transfer the UBQ from the E2 to a substrate. The UBQ is first attached to a conserved lysine residue within the HECT E3 and then conjugated to a substrate [71]. HECT E3 are known for only a few biological processes, such as biotic stress, trichome development, and leaf senescence [70,72].

In the following, we will focus on the main abiotic stress conditions for crop plants, which negatively impact yield worldwide. In this context, we provide examples for E3 ligases for each of these stressors, and how they are thought to impact plant stress tolerance and stress responses. These stress-specific examples can be taken as an opportunity to target specific steps in the cellular network controlling abiotic stress responses. This can lead to the development of novel strategies for bioengineering resilient crop plants, with the aim of securing food production through sustainable agriculture in the upcoming years.

\section{Drought Stress}

Drought stress is one of the most widespread abiotic stresses that negatively affects crop productivity [73]. A recent study has shown that the reduction of crop yield due to drought stress ranges between 30-90\%, depending on the crop species [74]. Drought arises when the amount of water in the soil is decreased and/or environmental conditions provoke continuous loss of water via transpiration or evaporation [75]. In the past years, E3 ligases have been established as important regulators of the drought stress response (Table 1), which we illustrate in several examples. 
Table 1. Plant E3 ligases involved in abiotic stress tolerance.

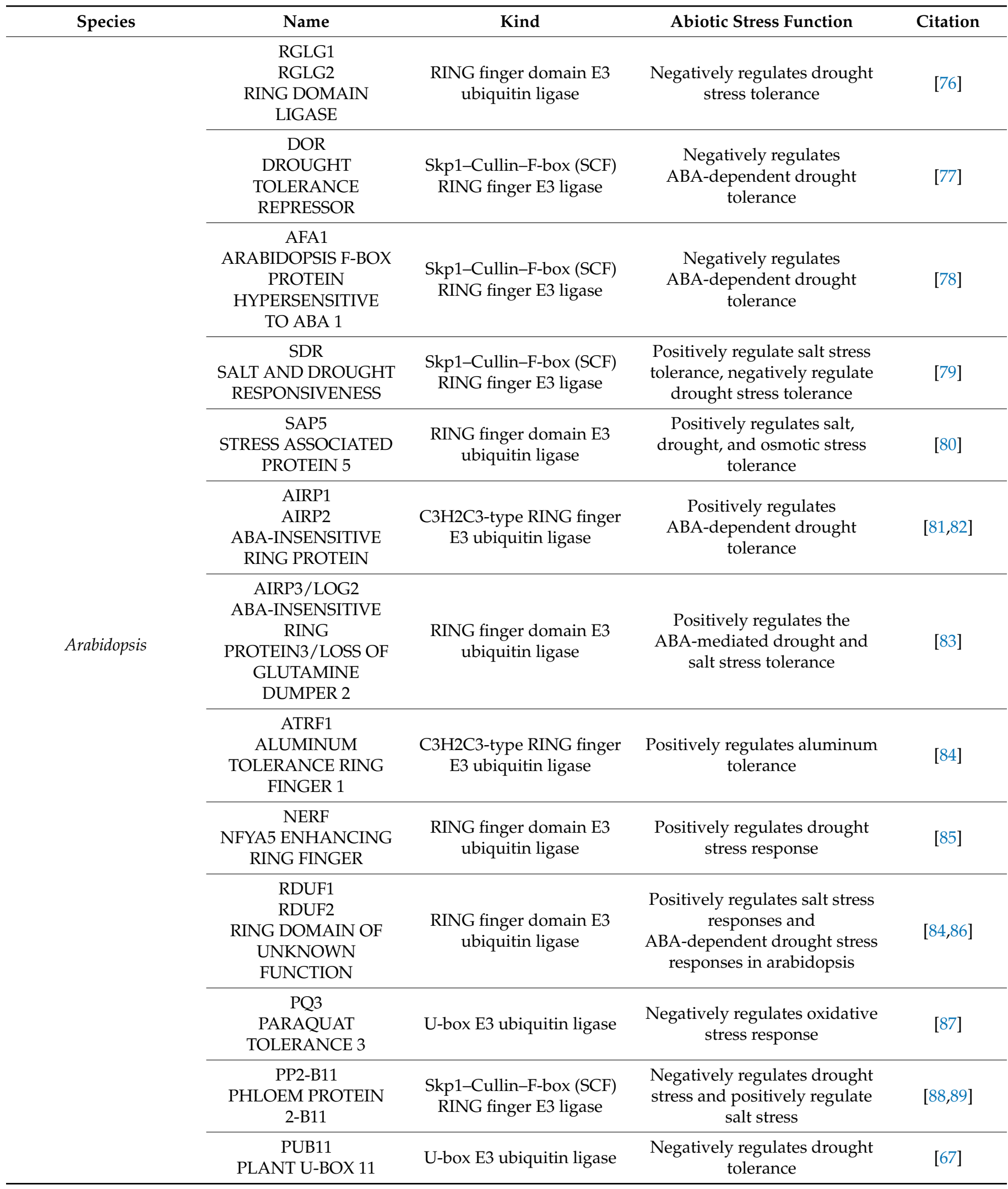


Table 1. Cont.

\begin{tabular}{|c|c|c|c|c|}
\hline Species & Name & Kind & Abiotic Stress Function & Citation \\
\hline & $\begin{array}{c}\text { PUB19 } \\
\text { PLANT U-BOX } 19\end{array}$ & U-box E3 ubiquitin ligase & $\begin{array}{l}\text { Negatively regulates drought } \\
\text { stress tolerance }\end{array}$ & [90] \\
\hline & $\begin{array}{c}\text { PUB22 } \\
\text { PUB23 } \\
\text { PLANT U-BOX }\end{array}$ & U-box E3 ubiquitin ligase & $\begin{array}{l}\text { Negatively regulates drought } \\
\text { stress tolerance }\end{array}$ & {$[66]$} \\
\hline & $\begin{array}{c}\text { PUB30 } \\
\text { PLANT U-BOX } 30\end{array}$ & U-box E3 ubiquitin ligase & $\begin{array}{l}\text { Negatively regulates the salt } \\
\text { stress tolerance during } \\
\text { germination }\end{array}$ & [91] \\
\hline & $\begin{array}{c}\text { PUB46 } \\
\text { PLANT U-BOX }\end{array}$ & U-box E3 ubiquitin ligase & $\begin{array}{l}\text { Positively regulates oxidative } \\
\text { stress tolerance }\end{array}$ & [92] \\
\hline & $\begin{array}{c}\text { PUB46 } \\
\text { PUB48 } \\
\text { PLANT U-BOX }\end{array}$ & U-box E3 ubiquitin ligase & $\begin{array}{l}\text { Positively regulate drought } \\
\text { stress tolerance }\end{array}$ & [93] \\
\hline & $\begin{array}{c}\text { PUB48 } \\
\text { PLANT U-BOX } 48\end{array}$ & U-box E3 ubiquitin ligase & $\begin{array}{l}\text { Positively regulates heat } \\
\text { tolerance }\end{array}$ & [94] \\
\hline & $\begin{array}{c}\text { SDIR1 } \\
\text { SALT- AND } \\
\text { DROUGHT-INDUCED } \\
\text { RING FINGER1 }\end{array}$ & $\begin{array}{l}\text { RING finger domain E3 } \\
\text { ubiquitin ligase }\end{array}$ & $\begin{array}{l}\text { Positively regulates ABA } \\
\text { dependent salt and drought } \\
\text { stress tolerance }\end{array}$ & [95] \\
\hline & $\begin{array}{c}\text { PRU1 } \\
\text { PHOSPHATE } \\
\text { RESPONSE } \\
\text { UBIQUITIN E3 } \\
\text { LIGASE1 }\end{array}$ & $\begin{array}{l}\text { RING finger domain E3 } \\
\text { ubiquitin ligase }\end{array}$ & $\begin{array}{c}\text { Modulates Pi homeostasis in } \\
\text { response to low-Pi stress in } \\
\text { Arabidopsis }\end{array}$ & [96] \\
\hline & $\begin{array}{c}\text { HOS1 } \\
\text { HIGH EXPRESSION } \\
\text { OF OSMOTICALLY } \\
\text { RESPONSIVE GENE } 1\end{array}$ & $\begin{array}{l}\text { RING finger domain E3 } \\
\text { ubiquitin ligase }\end{array}$ & $\begin{array}{l}\text { Negatively regulates the cold } \\
\text { stress response in Arabidopsis }\end{array}$ & {$[97,98]$} \\
\hline & $\begin{array}{c}\text { DUF1 } \\
\text { DUF2 } \\
\text { DOMAIN OF } \\
\text { UNKNOWN } \\
\text { FUNCTION }\end{array}$ & $\begin{array}{l}\text { RING finger domain E3 } \\
\text { ubiquitin ligase }\end{array}$ & $\begin{array}{l}\text { Positively regulates ABA } \\
\text { dependent drought stress } \\
\text { response }\end{array}$ & [99] \\
\hline & $\begin{array}{c}\text { ATL61 } \\
\text { ATL78 } \\
\text { ARABIDOPSIS } \\
\text { TÓXICOS EN } \\
\text { LEVADURA }\end{array}$ & $\begin{array}{c}\text { C3H2C3 RING finger } \\
\text { domain E3 ubiquitin ligase }\end{array}$ & $\begin{array}{l}\text { Negatively regulates cold } \\
\text { stress response and a } \\
\text { positively regulates drought } \\
\text { stress response }\end{array}$ & {$[100,101]$} \\
\hline & $\begin{array}{c}\text { STRF1 SALT } \\
\text { TOLERANCE RING } \\
\text { FINGER } 1\end{array}$ & $\begin{array}{l}\text { RING finger domain E3 } \\
\text { ubiquitin ligase }\end{array}$ & Positively regulates salt stress & [102] \\
\hline & $\begin{array}{c}\text { JUL1 } \\
\text { JAV1-ASSOCIATED } \\
\text { UBIQUITIN LIGASE1 }\end{array}$ & $\begin{array}{c}\text { C3H2C3 RING finger } \\
\text { domain E3 ubiquitin ligase }\end{array}$ & $\begin{array}{l}\text { Positively regulates drought } \\
\text { stress }\end{array}$ & [103] \\
\hline & $\begin{array}{c}\text { SR1 } \\
\text { SUBMERGENCE } \\
\text { RESISTANT1 }\end{array}$ & $\begin{array}{l}\text { RING finger domain E3 } \\
\text { ubiquitin ligase }\end{array}$ & $\begin{array}{l}\text { Negatively regulates } \\
\text { submergence tolerance }\end{array}$ & [104] \\
\hline
\end{tabular}


Table 1. Cont.

\begin{tabular}{|c|c|c|c|c|}
\hline Species & Name & Kind & Abiotic Stress Function & Citation \\
\hline & $\begin{array}{c}\text { PPRT1 } \\
\text { PROTEIN WITH THE } \\
\text { RING DOMAIN AND } \\
\text { TMEMB } 1\end{array}$ & $\begin{array}{c}\text { C3H2C3 RING finger } \\
\text { domain E3 ubiquitin ligase }\end{array}$ & $\begin{array}{c}\text { Negatively regulates salt stress } \\
\text { response. } \\
\text { positive role in regulating the } \\
\text { high temperature. } \\
\text { Negative role in ABA and } \\
\text { drought stress responses }\end{array}$ & [105-107] \\
\hline & $\begin{array}{c}\text { RHA2B } \\
\text { RHA2A } \\
\text { RING-H2 FINGER } \\
\text { PROTEIN 2B/2A }\end{array}$ & $\begin{array}{l}\text { RING finger domain E3 } \\
\text { ubiquitin ligase }\end{array}$ & $\begin{array}{l}\text { Positively regulates } \\
\text { ABA-dependent drought } \\
\text { response }\end{array}$ & {$[108,109]$} \\
\hline & $\begin{array}{c}\text { RZP34/CHYR1 } \\
\text { RING ZINC-FINGER } \\
\text { PROTEIN34/CHY } \\
\text { ZINC-FINGER AND } \\
\text { RING PROTEIN1 }\end{array}$ & $\begin{array}{l}\text { RING finger domain E3 } \\
\text { ubiquitin ligase }\end{array}$ & $\begin{array}{l}\text { Positively regulates drought } \\
\text { stress tolerant }\end{array}$ & [110] \\
\hline & $\begin{array}{c}\text { XBAT35.2 } \\
\text { XB3 ORTHOLOG } 5 \text { IN } \\
\text { ARABIDOPSIS } \\
\text { THALIANA }\end{array}$ & $\begin{array}{l}\text { RING finger domain E3 } \\
\text { ubiquitin ligase }\end{array}$ & $\begin{array}{c}\text { Negatively regulates the } \\
\text { drought and salt stress } \\
\text { response }\end{array}$ & [111] \\
\hline \multirow{8}{*}{$\begin{array}{c}\text { Rice } \\
\text { Oryza sativa }\end{array}$} & $\begin{array}{c}\text { AIR4.1 } \\
\text { AIR4.2 } \\
\text { ARSENIC-INDUCED } \\
\text { RING E3 LIGASE4 }\end{array}$ & $\begin{array}{l}\text { RING finger domain E3 } \\
\text { ubiquitin ligase }\end{array}$ & $\begin{array}{c}\text { Positively regulates Arsenic } \\
\text { stress tolerance }\end{array}$ & [112] \\
\hline & $\begin{array}{c}\text { CBE1 } \\
\text { CULLIN4-BASED E3 } \\
\text { UBIQUITIN LIGASE1 }\end{array}$ & $\begin{array}{l}\text { Cullin4-Based E3 Ubiquitin } \\
\text { Ligase }\end{array}$ & $\begin{array}{l}\text { Negatively regulates abiotic } \\
\text { stress tolerance }\end{array}$ & [113] \\
\hline & $\begin{array}{c}\text { DSG1 } \\
\text { DELAYED SEED } \\
\text { GERMINATION } 1\end{array}$ & $\begin{array}{l}\text { RING finger domain E3 } \\
\text { ubiquitin ligase }\end{array}$ & $\begin{array}{l}\text { Negatively regulates salt and } \\
\text { drought stress tolerance }\end{array}$ & [114] \\
\hline & $\begin{array}{c}\text { RDCPS } \\
\text { RING DOMAIN- } \\
\text { CONTAINING } \\
\text { PROTEINS }\end{array}$ & $\begin{array}{l}\text { RING finger domain E3 } \\
\text { ubiquitin ligase }\end{array}$ & $\begin{array}{l}\text { Positively regulates drought } \\
\text { stress tolerant }\end{array}$ & [115] \\
\hline & $\begin{array}{c}\text { DIS1 } \\
\text { DROUGHT-INDUCED } \\
\text { SINA PROTEIN } 1\end{array}$ & $\begin{array}{c}\text { C3HC4 RING finger } \\
\text { domain E3 ubiquitin ligase }\end{array}$ & $\begin{array}{c}\text { Negatively Regulates drought } \\
\text { response }\end{array}$ & [116] \\
\hline & $\begin{array}{c}\text { HIR1 } \\
\text { HEAVY METAL } \\
\text { INDUCED RING E3 } \\
\text { LIGASE } 1\end{array}$ & $\begin{array}{l}\text { RING finger domain E3 } \\
\text { ubiquitin ligase }\end{array}$ & $\begin{array}{l}\text { Positively regulates heavy } \\
\text { metal tolerance }\end{array}$ & [117] \\
\hline & $\begin{array}{c}\text { HIRP1 } \\
\text { HEAT INDUCED } \\
\text { RING FINGER } \\
\text { PROTEIN } 1\end{array}$ & $\begin{array}{l}\text { RING finger domain E3 } \\
\text { ubiquitin ligase }\end{array}$ & $\begin{array}{l}\text { Positively regulates plant } \\
\text { response to heat stress }\end{array}$ & [118] \\
\hline & $\begin{array}{c}\text { MAR1 } \\
\text { MICROTUBULE- } \\
\text { ASSOCIATED RING } \\
\text { FINGER PROTEIN } 1\end{array}$ & $\begin{array}{l}\text { RING finger domain E3 } \\
\text { ubiquitin ligase }\end{array}$ & $\begin{array}{l}\text { Negatively regulates the } \\
\text { salt-stress response }\end{array}$ & [119] \\
\hline
\end{tabular}


Table 1. Cont.

\begin{tabular}{|c|c|c|c|c|}
\hline Species & Name & Kind & Abiotic Stress Function & Citation \\
\hline & $\begin{array}{c}\text { RHP1 } \\
\text { RING-H2 FINGER } \\
\text { PROTEIN } 1\end{array}$ & $\begin{array}{l}\text { RING finger domain E3 } \\
\text { ubiquitin ligase }\end{array}$ & $\begin{array}{l}\text { Positively regulates salt and } \\
\text { drought stress tolerance }\end{array}$ & [120] \\
\hline & $\begin{array}{c}\text { SDIR1 } \\
\text { SALT-AND } \\
\text { DROUGHT-INDUCED } \\
\text { RING FINGER } 1\end{array}$ & $\begin{array}{l}\text { RING finger domain E3 } \\
\text { ubiquitin ligase }\end{array}$ & $\begin{array}{l}\text { Positively regulates drought } \\
\text { stress tolerance }\end{array}$ & [121] \\
\hline & $\begin{array}{c}\text { SIRF1 } \\
\text { SALT INDUCED RING } \\
\text { FINGER PROTEIN }\end{array}$ & $\begin{array}{l}\text { RING finger domain E3 } \\
\text { ubiquitin ligase }\end{array}$ & $\begin{array}{l}\text { Positively regulates salt and } \\
\text { osmotic stress }\end{array}$ & [122] \\
\hline & $\begin{array}{c}\text { SIRP1 } \\
\text { SALT-INDUCED RING } \\
\text { PROTEIN } 1\end{array}$ & $\begin{array}{l}\text { RING finger domain E3 } \\
\text { ubiquitin ligase }\end{array}$ & $\begin{array}{l}\text { Negatively regulates of salinity } \\
\text { stress tolerance }\end{array}$ & [123] \\
\hline & $\begin{array}{c}\text { SIRP2 } \\
\text { SALT-INDUCED RING } \\
\text { PROTEIN } 2\end{array}$ & $\begin{array}{l}\text { RING finger domain E3 } \\
\text { ubiquitin ligase }\end{array}$ & $\begin{array}{l}\text { Positively regulates of salt and } \\
\text { osmotic stress tolerance }\end{array}$ & [124] \\
\hline & $\begin{array}{c}\text { SIRP3 } \\
\text { SALT-INDUCED RING } \\
\text { PROTEIN } 3\end{array}$ & $\begin{array}{l}\text { RING finger domain E3 } \\
\text { ubiquitin ligase }\end{array}$ & $\begin{array}{l}\text { Negatively regulates salinity } \\
\text { stress response }\end{array}$ & [125] \\
\hline & $\begin{array}{c}\text { SIRP4 } \\
\text { SALT-INDUCED RING } \\
\text { PROTEIN } 4\end{array}$ & $\begin{array}{l}\text { RING finger domain E3 } \\
\text { ubiquitin ligase }\end{array}$ & $\begin{array}{c}\text { Negatively regulates salt stress } \\
\text { responses }\end{array}$ & [126] \\
\hline & $\begin{array}{c}\text { SIRH2- } 14 \\
\text { SALT-INSENSITIVE } \\
\text { RING-H2 TYPE } 14\end{array}$ & $\begin{array}{l}\text { RING finger domain E3 } \\
\text { ubiquitin ligase }\end{array}$ & $\begin{array}{l}\text { Positively regulates salt stress } \\
\text { tolerance }\end{array}$ & [127] \\
\hline & $\begin{array}{c}\text { SRFP1 } \\
\text { STRESS-RELATED } \\
\text { RING FINGER } \\
\text { PROTEIN } 1\end{array}$ & $\begin{array}{l}\text { RING finger domain E3 } \\
\text { ubiquitin ligase }\end{array}$ & $\begin{array}{l}\text { Negatively regulates salt, cold } \\
\text { and oxidative stresses }\end{array}$ & [128] \\
\hline & $\begin{array}{c}\text { PUB2 } \\
\text { PUB3 } \\
\text { PLANT U-BOX } \\
\text { 2AND 3 }\end{array}$ & U-box E3 ubiquitin ligase & $\begin{array}{l}\text { Positively regulates the } \\
\text { response to cold stress }\end{array}$ & [129] \\
\hline & $\begin{array}{c}\text { PUB15 } \\
\text { PLANT U-BOX } 15\end{array}$ & U-box E3 ubiquitin ligase & $\begin{array}{l}\text { Positively regulates oxidative } \\
\text { stress tolerance }\end{array}$ & [130] \\
\hline & $\begin{array}{c}\text { PUB41 } \\
\text { PLANT U-BOX41 }\end{array}$ & U-box E3 ubiquitin ligase & $\begin{array}{l}\text { Negatively regulates drought } \\
\text { stress response }\end{array}$ & [65] \\
\hline & $\begin{array}{c}\text { SADR1 } \\
\text { SALT, ABA, AND } \\
\text { DROUGHT } \\
\text { STRESS-INDUCED } \\
\text { RING FINGER } \\
\text { PROTEIN 1 }\end{array}$ & $\begin{array}{l}\text { RING finger domain E3 } \\
\text { ubiquitin ligase }\end{array}$ & $\begin{array}{c}\text { Negatively Regulates } \\
\text { Response to Salinity and } \\
\text { drought stress }\end{array}$ & [131] \\
\hline & $\begin{array}{c}\text { HOS1 } \\
\text { HIGH EXPRESSION } \\
\text { OF OSMOTICALLY } \\
\text { RESPONSIVE GENES } 1\end{array}$ & $\begin{array}{l}\text { RING finger domain E3 } \\
\text { ubiquitin ligase }\end{array}$ & $\begin{array}{l}\text { Negatively regulates the cold } \\
\text { stress response }\end{array}$ & [132] \\
\hline
\end{tabular}


Table 1. Cont.

\begin{tabular}{|c|c|c|c|c|}
\hline Species & Name & Kind & Abiotic Stress Function & Citation \\
\hline & $\begin{array}{c}\text { DIRP1 } \\
\text { DROUGHT-INDUCED } \\
\text { RING PROTEIN } 1\end{array}$ & $\begin{array}{l}\text { RING finger domain E3 } \\
\text { ubiquitin ligase }\end{array}$ & $\begin{array}{l}\text { Negatively regulates drought } \\
\text { and salt stress, and positively } \\
\text { regulates cold stress response } \\
\text { in rice }\end{array}$ & [133] \\
\hline & $\begin{array}{c}\text { DHSRP1 } \\
\text { DROUGHT-HEAT- } \\
\text { SALT INDUCED RING } \\
\text { FINGER PROTEIN } 1\end{array}$ & $\begin{array}{l}\text { RING finger domain E3 } \\
\text { ubiquitin ligase }\end{array}$ & $\begin{array}{l}\text { Negatively regulates drought, } \\
\text { heat, and salt stress tolerance }\end{array}$ & [134] \\
\hline \multirow{7}{*}{$\begin{array}{c}\text { Wheat } \\
\text { Triticum aestivum }\end{array}$} & $\begin{array}{c}\text { DIS1 } \\
\text { DROUGHT-INDUCED } \\
\text { SINA PROTEIN } 1\end{array}$ & $\begin{array}{c}\text { C3HC4 RING finger } \\
\text { domain E3 ubiquitin ligase }\end{array}$ & $\begin{array}{l}\text { Negatively regulates drought } \\
\text { stress tolerance }\end{array}$ & [135] \\
\hline & $\begin{array}{c}\text { FBA1 } \\
\text { FBOX-AMN1 }\end{array}$ & $\begin{array}{l}\text { Skp1-Cullin-F-box (SCF) } \\
\text { RING finger E3 ligase }\end{array}$ & $\begin{array}{c}\text { Positively regulates heat and } \\
\text { drought stress in wheat. } \\
\text { Positively regulates oxidative } \\
\text { stress }\end{array}$ & [136-138] \\
\hline & $\begin{array}{c}\text { PUB1 } \\
\text { PLANT U-BOX } 1\end{array}$ & U-box E3 ubiquitin ligase & $\begin{array}{l}\text { Positively regulates salt and } \\
\text { drought stress tolerance } \\
\text { in wheat. } \\
\text { Positively regulate Cadmium } \\
\text { stress tolerance }\end{array}$ & [139-141] \\
\hline & $\begin{array}{c}\text { PUB15 } \\
\text { PLANT U-BOX } 15\end{array}$ & U-box E3 ubiquitin ligase & $\begin{array}{l}\text { Positively regulates salt stress } \\
\text { tolerance in wheat }\end{array}$ & [142] \\
\hline & $\begin{array}{c}\text { PUB26 } \\
\text { PLANT U-BOX } 26\end{array}$ & U-box E3 ubiquitin ligase & $\begin{array}{c}\text { Negatively regulates salt stress } \\
\text { in wheat }\end{array}$ & [143] \\
\hline & $\begin{array}{c}\text { SAP5 } \\
\text { STRESS-ASSOCIATED } \\
\text { PROTEIN }\end{array}$ & $\begin{array}{l}\text { RING finger domain E3 } \\
\text { ubiquitin ligase }\end{array}$ & $\begin{array}{l}\text { Positively regulates drought } \\
\text { stress }\end{array}$ & [144] \\
\hline & $\begin{array}{l}\text { ZNF } \\
\text { ZINC-FINGER } \\
\text { PROTEIN }\end{array}$ & $\begin{array}{c}\text { C3HC4 RING finger } \\
\text { domain E3 ubiquitin ligase }\end{array}$ & $\begin{array}{c}\text { Positively regulates salt and } \\
\text { drought stress }\end{array}$ & [145] \\
\hline \multirow{5}{*}{$\begin{array}{c}\text { Pepper } \\
\text { Capsicum annuum }\end{array}$} & $\begin{array}{c}\text { ASRF1 } \\
\text { ABA SENSITIVE RING } \\
\text { FINGER E3 LIGASE } 1\end{array}$ & $\begin{array}{l}\text { RING finger domain E3 } \\
\text { ubiquitin ligase }\end{array}$ & $\begin{array}{l}\text { Positively regulates drought } \\
\text { stress tolerance in pepper }\end{array}$ & [146] \\
\hline & $\begin{array}{c}\text { AIRE1 } \\
\text { ABA INDUCED } \\
\text { RING-TYPE E3 } \\
\text { LIGASE } 1\end{array}$ & $\begin{array}{l}\text { RING finger domain E3 } \\
\text { ubiquitin ligase }\end{array}$ & $\begin{array}{l}\text { Positively regulates the } \\
\text { drought stress response in } \\
\text { pepper }\end{array}$ & [147] \\
\hline & $\begin{array}{c}\text { AIR1 } \\
\text { ABA-INSENSITIVE } \\
\text { RING PROTEIN } 1 \\
\text { GENE }\end{array}$ & $\begin{array}{l}\text { RING finger domain E3 } \\
\text { ubiquitin ligase }\end{array}$ & $\begin{array}{l}\text { Negatively regulates the } \\
\text { ABA-mediated drought stress } \\
\text { tolerance mechanism }\end{array}$ & [148] \\
\hline & $\begin{array}{c}\text { DTR1 } \\
\text { DROUGHT } \\
\text { TOLERANCE RING } 1\end{array}$ & $\begin{array}{l}\text { RING finger domain E3 } \\
\text { ubiquitin ligase }\end{array}$ & $\begin{array}{l}\text { Positively regulates the } \\
\text { drought stress response in } \\
\text { pepper }\end{array}$ & [149] \\
\hline & $\begin{array}{c}\text { ATIR1 } \\
\text { ATBZ1 INTERACTING } \\
\text { RING FINGER } \\
\text { PROTEIN } 1\end{array}$ & $\begin{array}{l}\text { RING finger domain E3 } \\
\text { ubiquitin ligase }\end{array}$ & $\begin{array}{l}\text { Positively regulates abscisic } \\
\text { acid signaling and drought } \\
\text { response }\end{array}$ & [150] \\
\hline
\end{tabular}


Table 1. Cont.

\begin{tabular}{|c|c|c|c|c|}
\hline Species & Name & Kind & Abiotic Stress Function & Citation \\
\hline & $\begin{array}{c}\text { REL1 } \\
\text { RING TYPE E3 } \\
\text { LIGASE 1 GENE }\end{array}$ & $\begin{array}{l}\text { RING finger domain E3 } \\
\text { ubiquitin ligase }\end{array}$ & $\begin{array}{c}\text { Negatively regulates } \\
\text { ABA-mediated drought stress } \\
\text { tolerance }\end{array}$ & [151] \\
\hline & $\begin{array}{c}\text { DIR1 } \\
\text { DROUGHT INDUCED } \\
\text { RING TYPE E3 } \\
\text { LIGASE } 1\end{array}$ & $\begin{array}{l}\text { RING finger domain E3 } \\
\text { ubiquitin ligase }\end{array}$ & $\begin{array}{l}\text { Negatively regulates the } \\
\text { drought stress response via } \\
\text { ABA-mediated signaling }\end{array}$ & [152] \\
\hline & $\begin{array}{c}\text { AIRF1 } \\
\text { ADIP1 INTERACTING } \\
\text { RING FINGER } \\
\text { PROTEIN 1 }\end{array}$ & $\begin{array}{l}\text { RING finger domain E3 } \\
\text { ubiquitin ligase }\end{array}$ & $\begin{array}{l}\text { Positively regulates the } \\
\text { drought stress response in } \\
\text { pepper }\end{array}$ & [153] \\
\hline \multirow{2}{*}{$\begin{array}{l}\text { Corn } \\
\text { Zea maiz }\end{array}$} & $\begin{array}{l}\text { AIRP4: ZEA MAYS } \\
\text { ABA INSENSITIVE } \\
\text { RING PROTEIN } 4\end{array}$ & $\begin{array}{l}\text { RING finger domain E3 } \\
\text { ubiquitin ligase }\end{array}$ & $\begin{array}{l}\text { Positively regulates the } \\
\text { drought tolerance response } \\
\text { pathway }\end{array}$ & [154] \\
\hline & $\begin{array}{c}\text { RFP1 } \\
\text { RING FINGER } \\
\text { PROTEIN } 1\end{array}$ & $\begin{array}{l}\text { RING finger domain E3 } \\
\text { ubiquitin ligase }\end{array}$ & $\begin{array}{l}\text { Positively regulates salt and } \\
\text { drought stress tolerance }\end{array}$ & [155] \\
\hline $\begin{array}{l}\text { Cotton } \\
\text { Gossypium hirsutum }\end{array}$ & $\begin{array}{c}\text { SARP1 } \\
\text { SALT-ASSOCIATED } \\
\text { RING FINGER } \\
\text { PROTEIN }\end{array}$ & $\begin{array}{c}\text { C3H2C3 RING finger } \\
\text { domain E3 ubiquitin ligase }\end{array}$ & $\begin{array}{l}\text { Negatively regulate the } \\
\text { response to salt stress }\end{array}$ & [156] \\
\hline $\begin{array}{l}\text { Tomato } \\
\text { Solanum lycopersicum }\end{array}$ & $\begin{array}{l}\text { RING1REALLY } \\
\text { INTERESTING NEW } \\
\text { GENE } 1\end{array}$ & $\begin{array}{l}\text { RING finger domain E3 } \\
\text { ubiquitin ligase }\end{array}$ & $\begin{array}{l}\text { Positively regulates } \mathrm{Cd} \\
\text { tolerance }\end{array}$ & [157] \\
\hline $\begin{array}{l}\text { Sickle medick } \\
\text { Medicago falcata }\end{array}$ & $\begin{array}{c}\text { STMIR } \\
\text { SALT TUNICAMYCIN- } \\
\text { INDUCED RING } \\
\text { FINGER PROTEIN }\end{array}$ & $\begin{array}{l}\text { RING finger domain E3 } \\
\text { ubiquitin ligase }\end{array}$ & Positively regulates salt stress & [158] \\
\hline $\begin{array}{c}\text { Wild tomato } \\
\text { Solanum pimpinellifolium }\end{array}$ & $\begin{array}{c}\text { RING } \\
\text { REALLY } \\
\text { INTERESTING NEW } \\
\text { GENE }\end{array}$ & $\begin{array}{l}\text { RING finger domain E3 } \\
\text { ubiquitin ligase }\end{array}$ & $\begin{array}{l}\text { Positively regulates salt stress } \\
\text { in wild tomato species }\end{array}$ & [159] \\
\hline $\begin{array}{l}\text { Apple } \\
\text { Malus domestica }\end{array}$ & $\begin{array}{c}\text { MIEL } \\
\text { MYB30- } \\
\text { INTERACTING E3 } \\
\text { LIGASE } 1\end{array}$ & $\begin{array}{l}\text { RING finger domain E3 } \\
\text { ubiquitin ligase }\end{array}$ & $\begin{array}{l}\text { Negatively regulates salt and } \\
\text { oxidative stresses tolerance }\end{array}$ & [160] \\
\hline $\begin{array}{l}\text { Soybean } \\
\text { Glycine max }\end{array}$ & $\begin{array}{c}\text { PUB6 } \\
\text { PUB8 } \\
\text { PLANT U-BOX }\end{array}$ & U-box E3 ubiquitin ligase & $\begin{array}{l}\text { Negative regulator of drought } \\
\text { stress response in Arabidopsis }\end{array}$ & {$[161,162]$} \\
\hline
\end{tabular}

Work on the A. thaliana RING DOMAIN LIGASE1 (AtRGLG1) has demonstrated its role in targeting and promoting degradation of three key substrates: ETHYLENE RESPONSE FACTOR53 (AtERF53), MITOGEN ACTIVATED PROTEIN KINASE KINASE KINASE 18 (MAPKKK18), and PROTEIN PHOSPHATASE 2CA (PP2CA) [76,163,164] (Figure 2). AtERF53 is a transcription factor that belongs to the AP2/ERF transcription factor family [165], and MAPKKK18 is a member of the MAPKKKs family, which includes 80 members in Arabidopsis. It plays a role in senescence regulation, abiotic stress signaling, and ABA responses [166,167]. 


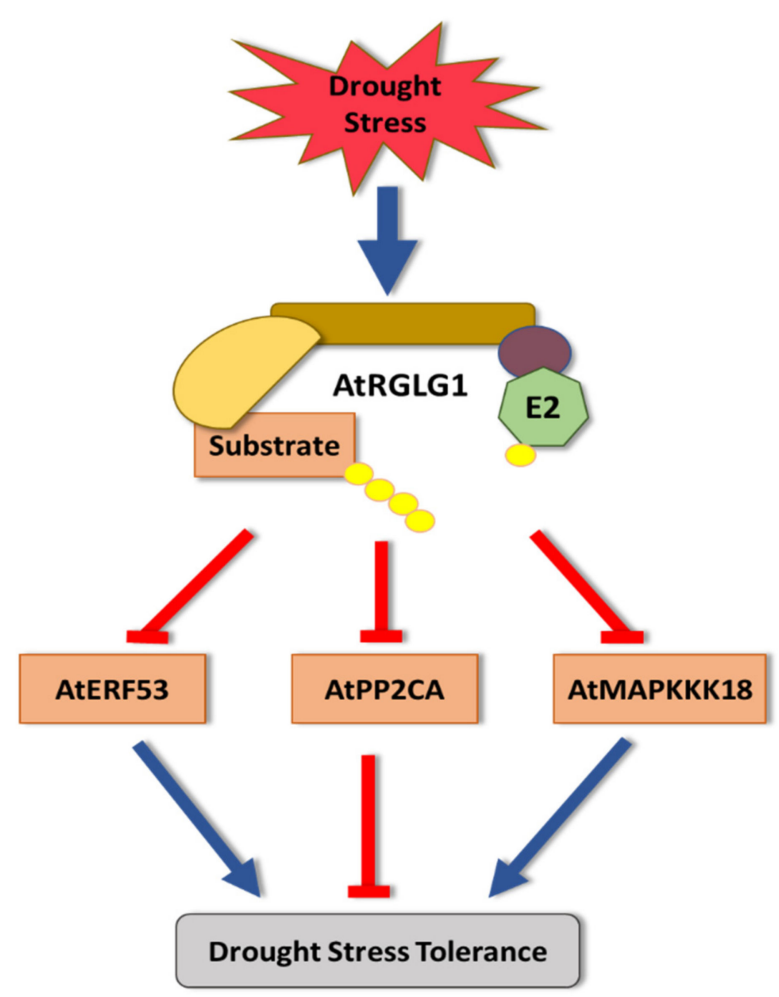

Figure 2. The role of $A$. thaliana RING DOMAIN LIGASE1 (AtRGLG1) in drought stress tolerance. AtRGLG1 targets three proteins critical for improving drought tolerance for proteasomal degradation: ETHYLENE RESPONSE FACTOR53 (AtERF53), MITOGEN ACTIVATED PROTEIN KINASE KINASE KINASE 18 (MAPKKK18), and PROTEIN PHOSPHATASE 2CA (PP2CA).

Atmapkkk18 knockout transgenic lines have impaired stomatal closure and exhibit hypersensitivity toward drought stress. Transgenic lines overexpressing AtERF53 or AtMAPKKK18 in Arabidopsis showed increased drought tolerance compared to wildtype plants [76]. It has been shown that both RGLG1, and its closest sequelog RGLG2, negatively regulate drought stress tolerance by targeting and mediating the degradation of AtERF53 and AtMAPKKK18 [76,163]. In agreement with that, rglg1/rglg2 double mutant lines showed increased AtERF53 and AtMAPKKK18 stability, and enhanced drought tolerance [167]. Additionally, even more robust drought tolerance was obtained when MAPKKK18 or AtERF53 were overexpressed in the $r g l g 1 / \mathrm{rg} \lg 2$ background. [163,165].

The third AtRGLG1 substrate, PP2CA, acts as a negative regulator of abscisic acid (ABA) signaling and ABA- dependent drought stress tolerance [168]. RGLG1 functions as a positive $\mathrm{ABA}$ response regulator by mediating PP2CA protein degradation, which then promotes ABA-mediated drought tolerance [164,169].

It seems that RGLG1 plays opposite roles in drought stress tolerance. It acts as a negative regulator by targeting both ERF53 and MAPKKK18, but functions as a positive regulator by targeting PP2CA (Figure 2). While this indicates the important role that RGLG1 plays in balancing the response toward drought stress, the mechanisms in which it does that are still not understood.

Another RING finger E3 ligase in Arabidopsis and wheat (Triticum aestivum) that positively regulates drought stress tolerance is STRESS-ASSOCIATED PROTEIN 5 (TaSAP5), which mediates the degradation of DREB2A INTERACTING PROTEIN 1 (DRIP1) and DRIP2 [144]. DRIPs are RING finger E3 ligases that function as negative regulators of the drought stress response by facilitating degradation of DEHYDRATION-RESPONSIVE ELEMENT BINDING PROTEIN 2A (DREB2A) [170], an ERF/AP2 transcription factor known as a key regulator for drought and heat stress tolerance $[28,171]$. Overexpression of TaSAP5 enhances the stability of DREB2A, which in turn upregulates drought-responsive genes, and improves drought tolerance in transgenic Arabidopsis and wheat plants [144]. 
In Arabidopsis, the expression of the F-box protein DROUGHT TOLERANCE REPRESSOR 1 (DOR1), a subunit of SKP1, CULLIN1, F-BOX (SCF) E3 ligase, was downregulated under both drought stress treatment and exogenous $\mathrm{ABA}$ application [77]. dor1 mutant lines are hypersensitive toward $\mathrm{ABA}$, leading to stomatal closure, providing increased drought tolerance. On the other hand, overexpression of DOR1 leads to increased drought sensitivity, indicating that DOR1 act as a negative regulator of drought stress tolerance [77].

Many members of PLANT U BOX (PUB) E3 ligases have been shown to be involved in drought stress tolerance regulation (Table 1). In Arabidopsis, PUB11 negatively regulates drought stress response by targeting LEUCINE RICH REPEAT PROTEIN 1 (LRR1) and KINASE 7 (KIN7) for degradation via the 26S proteasome [67]. Both LRR1 and KIN7 are needed to promote stomatal closure during water stress conditions [172,173]. On the other hand, Arabidopsis PUB46 and PUB48 act as positive regulators of drought stress since pub46/pub48 double mutants become drought hypersensitive [93]. Although there is currently no information on their target substrates, it can be expected that they negatively regulate drought stress responses [93] (Figure 3).

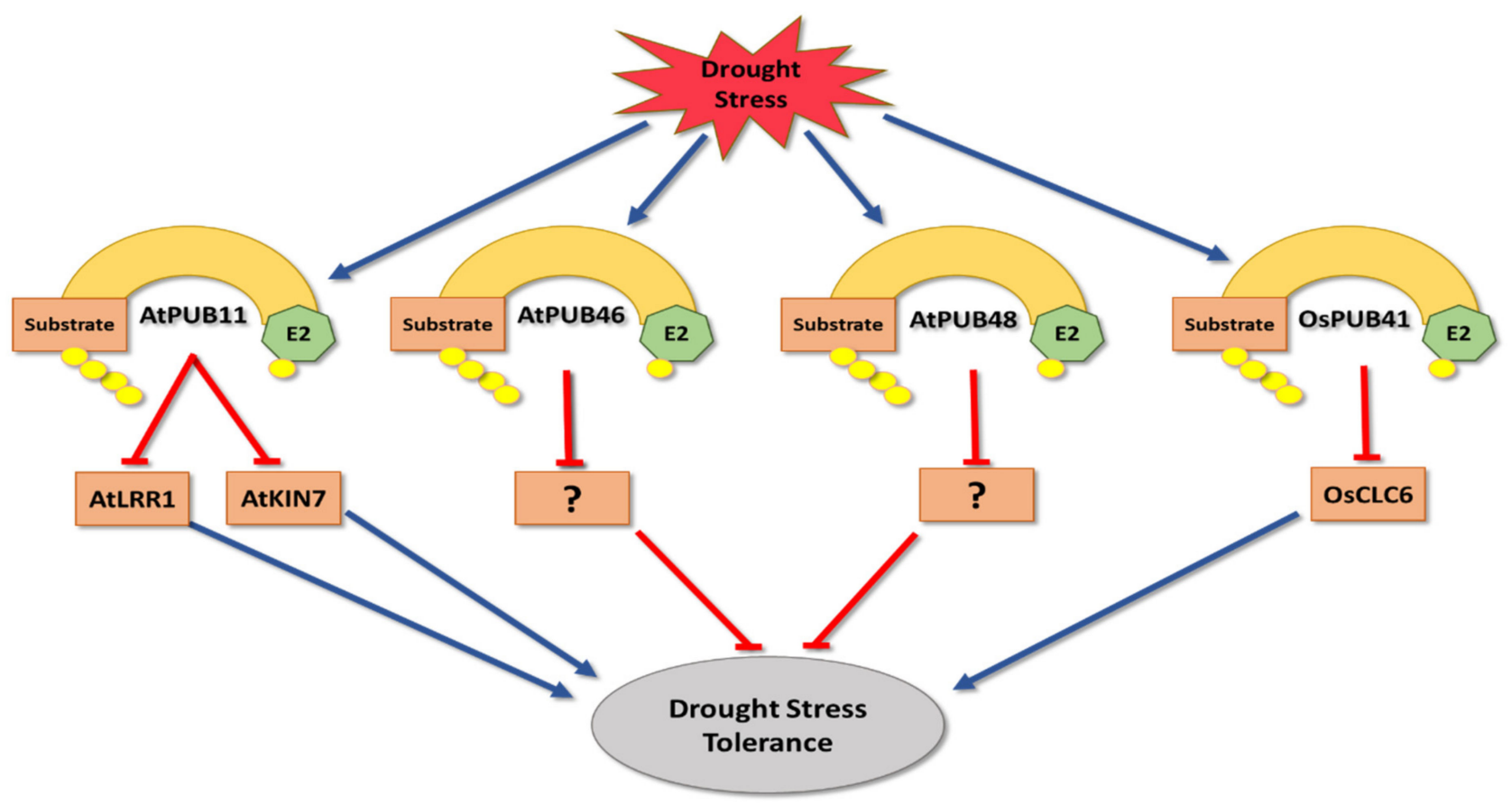

Figure 3. The role of PLANT U-BOX E3 ligases (PUBs) in drought stress tolerance. Both $A$. thaliana PUB46 and PUB48 positively regulate drought tolerance by targeting unknown substrates, which are suggested to be negative regulators of drought tolerance. On the other hand, AtPUB11 negatively regulates drought tolerance by targeting both LEUCINE RICH REPEAT PROTEIN 1 (LRR1) and KINASE 7 (KIN7), which are known as positive regulators of drought tolerance. Also, O. sativa PUB41 is considered to be a negative regulator of drought tolerance by targeting CHLORIDE CHANNEL 6 (OsCLC6).

In rice, OsPUB41 has been described as a negative regulator of drought stress tolerance. This E3 ligase is highly expressed under drought conditions, and compared to wildtype, ospub41 null mutants have enhanced tolerance towards water deficit stress [65]. OsPUB41 triggers the degradation of CHLORIDE CHANNEL 6 (OsCLC6), a protein critical for drought stress tolerance [65], and part of a family that functions in modifying chlorine ion homeostasis under drought conditions [174] (Figure 3).

From stomatal closure to ABA response and chlorine ion homeostasis, E3 ligases have an important role in the regulation of drought response in plants. This section, with the selected examples, clearly demonstrates the relevance of plant E3 ligases in both positive 
and negative regulation of drought stress tolerance. It further emphasizes that these E3 ligases may represent critical tools to produce more resilient crop plants that better withstand drought stress in the future.

\section{Salt Stress}

Salinity in irrigation water sources and soil is a major environmental challenge due to the negative effects on plant growth, development, and productivity, especially in arid and semi-arid regions [175]. In the Middle East, more than 100 million hectares, around $6 \%$ of the total land area, consist of salinized soil or carries high sodium levels [176]. Globally, around $69 \%$ of wheat production is threatened by the negative influence of soil salinity [176]. Over the last two decades this issue has worsened due to the rising need to irrigate continually expanding arid regions, which often increases salt content in treated fields over time [177].

Under salt stress, several physiological and biochemical mechanisms are activated in plants, which can impact photosynthesis, distribution of harmful ions, and other biochemical adaptations [178,179]. It has been shown that several E3 ligases are involved in regulating these responses by targeting and mediating the degradation of salt stress-related proteins (Table 1).

In Arabidopsis, loss-of-function mutants affected in a plasma membrane associated RING finger E3 ligase called SALT TOLERANCE RING FINGER 1 (STRF1) displayed enhanced salt stress tolerance and decreased reactive oxygen species (ROS) accumulation. Although proteins targeted by this E3 ligase are still unknown, these findings indicate that STRF1 is a negative regulator of salt stress responses [102].

Rice expresses many RING finger E3 ligases that are involved in salt stress regulation, such as the SALT-INDUCED RING PROTEIN family (SIRP) [123-126] (Figure 4). Three of the four members have been described as negative regulators of salinity stress responses [123]. Overexpression of OSSIRP1 in Arabidopsis showed a reduction in salinity tolerance during seed germination and root elongation growth, which is a likely impact of the degradation of its still undefined target proteins [123]. Similarly, plants overexpressing OsSIRP3 and OsSIRP4 exhibit hypersensitivity to salt stress conditions $[125,126]$. OsSIRP3 accomplishes this by triggering degradation of two salt-induced substrate proteins, $O$. sativa MADS-BOX GENE 70 (OsMADS70) and an ABC DOMAIN CONTAINING PROTEIN (OsABC1P11) [125]. OsSIRP4 regulates the degradation of O. sativa PEROXISOMAL BIOGENESIS FACTOR 11-1 (OsPEX11-1) by the 26S proteasome [126]. However, it is currently unclear how exactly salt stress tolerance is affected by the OsSIRP4/OsPEX11-1 interaction [126].

On the other hand, overexpression of OsSIRP2 E3 ligase enhances resistance towards salt and osmotic stress in Arabidopsis [124]. Yeast two-hybrid (Y2H) and pulldown assays have demonstrated physical interaction between OsSIRP2 and a potential target, O. sativa TRANSKETOLASE 1 (OsTKL1) [124]. OsTKL1 belongs to the transketolase family involved in the regeneration of ribulose 1,5-bisphosphate within the Calvin cycle [180,181], but it remains an open question as to how its ubiquitination and degradation affects salt stress responses [124].

As mentioned, four SIRP E3 ligases have been described to be involved in positive or negative regulation of salt stress tolerance. Although their mechanism of action is still unknown, they are good examples of E3 ligases that could be targeted for genetic modification to improve salinity tolerance in rice.

In cotton (Gossypium hirsutum), the RING finger E3 ligase SALT-ASSOCIATED RING FINGER PROTEIN (GhSARP1) is described as a negative regulator of salt stress tolerance [156]. When overexpressed in Arabidopsis, GhSARP1 enhanced salt stress sensitivity in transgenic plants during germination and seedling stages [156].

Currently, little is known about the role of PLANT U-BOX (PUB) E3 ligases in abiotic stress tolerance in wheat. Recently TaPUB15 was described as a positive regulator of salt stress tolerance, since overexpression of TaPUB15 in both Arabidopsis and rice increased 
salt stress tolerance [142]. The transgenic lines showed deeper and more branched root development along with improved maintenance of low $\mathrm{Na}^{+} / \mathrm{K}^{+}$ratios under salt stress when compared to wild type. Targets of TaPUB15 are currently unknown [142].

In contrast, TaPUB26 acts as a negative regulator of salt stress tolerance [143]. Here, stiff brome (Brachypodium distachyon) transgenic lines overexpressing this E3 ligase exhibited higher sensitivity toward salinity, which was accompanied by accumulation of ROS, and an increased $\mathrm{Na}^{+} / \mathrm{K}^{+}$ratio [143]. TaPUB26 interacts with T. aestivum REGULATORY PARTICLE AAA-ATPASE 2A (TaRPT2a), which functions as an ATPase subunit of the 26S proteasome complex. Its gene expression is salt inducible, however the mechanism of how TaPUB26-TaRPT2a interaction affects salt stress tolerance is still not understood [143].

With increasing arid land that will require expanded irrigation systems, understanding how to address the impacts of salt on agriculture has become quite relevant. Work across a diverse group of plants underscores that E3 ligases are central players in how pathways are controlled when higher salt levels are present. Identification of substrates degraded by RING-finger and PUB E3s that are linked to salt stress response is providing some possible mechanisms that could be modulated to allow continued farming in areas like the Middle East, which will continue to see diminishing arable fields.

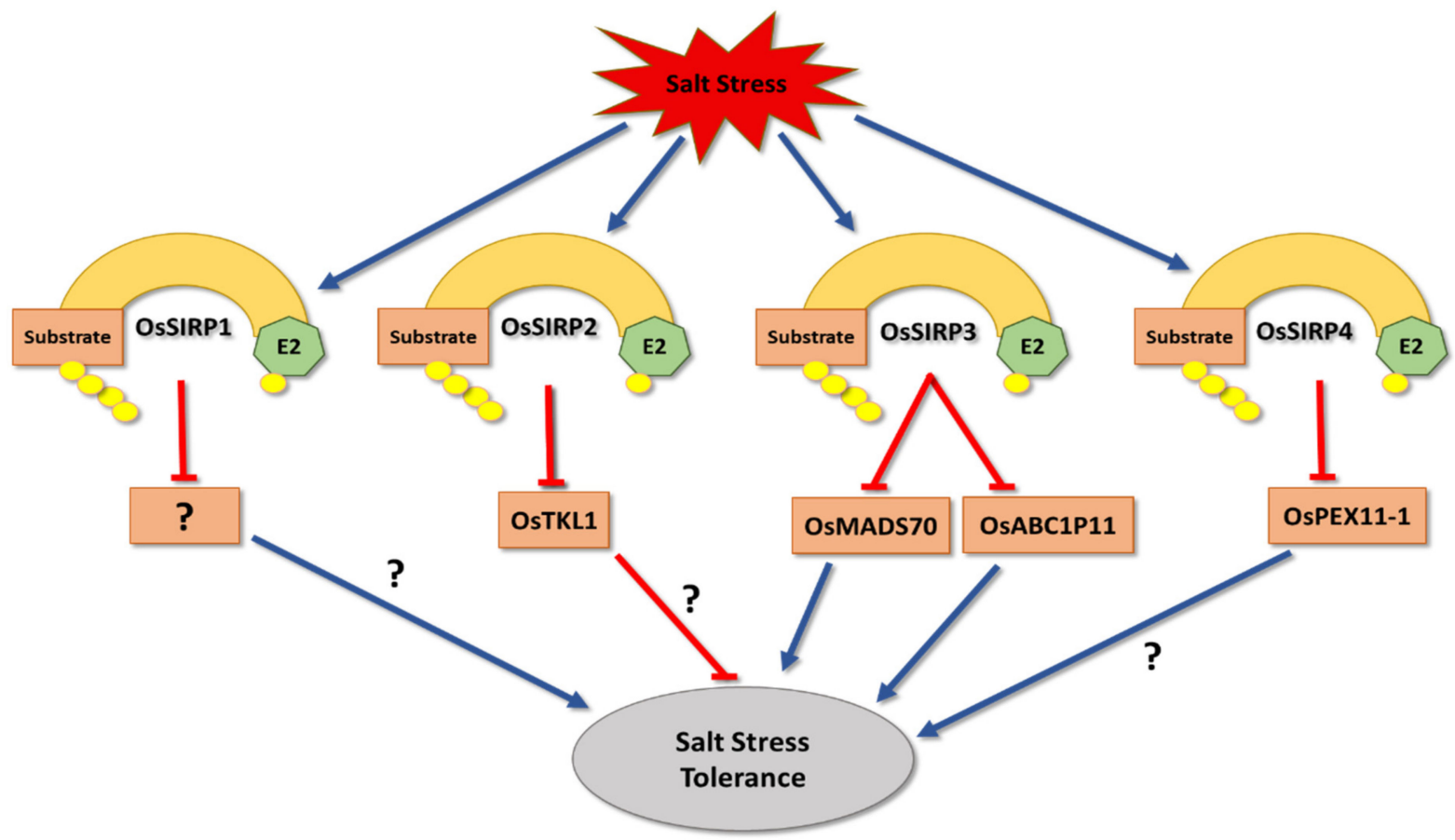

Figure 4. The role of $O$. sativa SALT-INDUCED RING PROTEIN family (SIRPs) in salt stress tolerance. OsSIRP1 negatively regulates salt tolerance by targeting unknown substrates that are suggested to be positive regulators of salt tolerance. Also, OsSIRP3 negatively regulates salt tolerance by triggering degradation of two salt-induced proteins, O. sativa MADS-BOX GENE 70 (OsMADS70) and an ABC DOMAIN CONTAINING PROTEIN (OsABC1P11). Moreover, OsSIRP4 is a negative regulator of salt stress tolerance by targeting $O$. sativa PEROXISOMAL BIOGENESIS FACTOR 11-1 (OsPEX11-1), which has an unknown function related to salt stress regulation. On the other hand, OsSIRP2 is considered to be a positive regulator of salt tolerance by targeting its only known target substrate, TRANSKETOLASE 1 (OsTKL1).

\section{Oxidative Stress}

Although oxygen $\left(\mathrm{O}_{2}\right)$ is a fundamental element for land plants to obtain their energy resources by cellular respiration; it generates another challenge through the formation of ROS, such as superoxide $\left(\mathrm{O}_{2}{ }^{-}\right)$, hydrogen peroxide $\left(\mathrm{H}_{2} \mathrm{O}_{2}\right)$, or hydroxyl radicals $(\mathrm{OH})$ [182] ROS generally affect plant growth and development negatively via protein oxidation, lipid 
peroxidation, nucleic acid damage, enzyme deactivation, and cell death enhancement [183]. The rise in ROS can be observed by prolonged exposure to any abiotic stress, independent of whether it is e.g., salt, drought, or excessive light [184].

Only a few E3 ligases have been described to regulate oxidative stress tolerance (Table 1). For example, Arabidopsis PARAQUAT TOLERANCE 3 (PQT3), a member of RING finger/U-box E3 ligases, has been identified as a major oxidative stress regulator [185] (Figure 5). Protein interaction assays showed that PQT3 directly interacts with PROTEIN ARGININE METHYLTRANSFERASE 4B (AtPRMT4B), which plays a role in upregulating the expression of both ASCORBATE PEROXIDASE 1 (APX1) and GLUTATHIONE PEROXIDASE 1 (GPX1). These play major roles in oxidative stress tolerance by acting as antioxidant enzymes to catalyze the reduction of $\mathrm{H}_{2} \mathrm{O}_{2}$ to water and oxygen $[186,187]$. Under oxidative stress, $P Q T 3$ expression is suppressed, which leads to an accumulation of PRMT4B. PRMT4B, in turn, enhances the histone methylation around APX1 and GPX1 gene loci, signaling increases in their expression level [185]. When ROS levels return to normal, PQT3 suppression is released, causing a down regulation of APX1 and GPX1, which characterizes PQT3 as a negative regulator of oxidative stress tolerance [185].

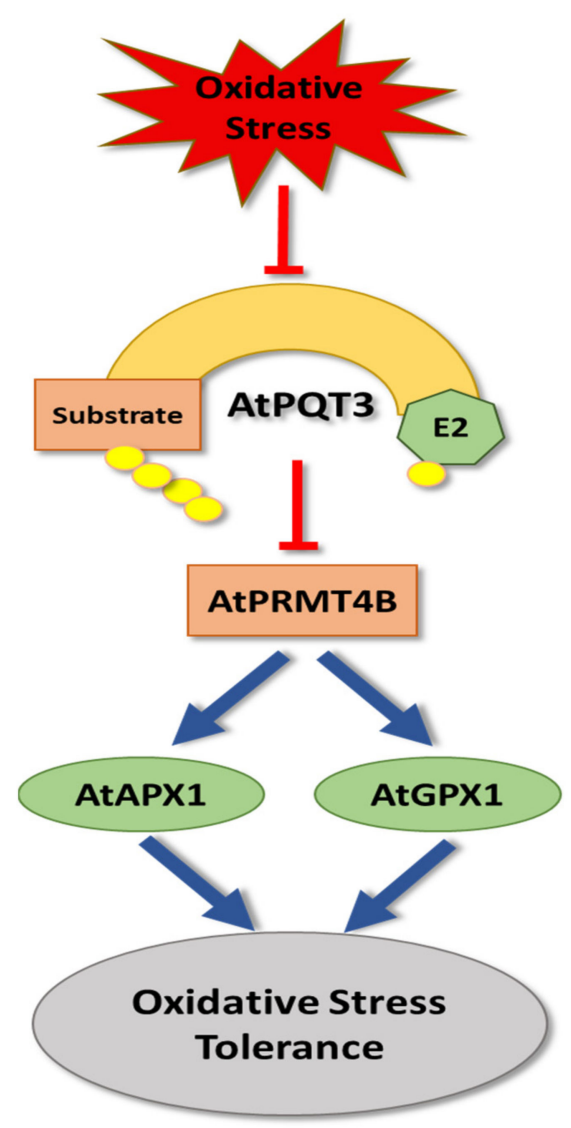

Figure 5. The role of $A$. thaliana PARAQUAT TOLERANCE 3 (PQT3) in oxidative stress tolerance. AtPQT3 negatively regulates oxidative stress tolerance by triggering degradation of PROTEIN ARGININE METHYLTRANSFERASE 4B (AtPRMT4B), which promotes ASCORBATE PEROXIDASE 1 (APX1) and GLUTATHIONE PEROXIDASE 1 (GPX1) expression. Both APX1 and GPX1 play major roles in oxidative stress tolerance by acting as antioxidants that catalyze the reduction of $\mathrm{H}_{2} \mathrm{O}_{2}$ to water and oxygen.

Because the mechanism of action for PQT3 is well understood, this E3 ligase could be a potential candidate for genetic engineering to improve oxidative stress tolerance in crop plants.

In wheat the F-box protein F-BOX-ANTAGONIST OF MITOTIC EXIT NETWORK PROTEIN 1 (TaFBA1) is a subunit of SKP1, CULLIN, F-BOX (SCF) E3 ligase. Expression was 
up-regulated under oxidative stress treatment, and overexpression of TaFBA1 in transgenic tobacco plants resulted in increased activities of oxidative stress-related enzymes, such as catalase (CAT), peroxidase (POD), and superoxide dismutase (SOD) [138]. In addition to its role in oxidative stress tolerance, TaFBA1 has been described as a positive regulator of both heat and drought stress tolerance [136,137], making this an interesting candidate for the possible enhancement of yield in wheat under a range of abiotic stresses.

TaPUB1, another example from wheat, has been shown to function as a positive regulator of drought stress tolerance by enhancing cellular antioxidant capacity levels [140]. Under drought stress, transgenic plants that overexpressed TaPUB1 showed increased CAT and SOD activities, compared to wild type, and accumulated less $\mathrm{O}_{2}{ }^{-}$and $\mathrm{H}_{2} \mathrm{O}_{2}$ [140].

The rice U-box E3 ligase OsPUB15 is also involved in oxidative stress tolerance with elevated expression under oxidative stress conditions [130]. ospub15 mutant lines showed acute growth retardation during seedling establishment, likely corresponding to the observed increase in ROS and oxidized protein levels [130]. On the other hand, transgenic lines that overexpressed OsPUB15 showed better growth than wild type when exposed to paraquat [130]. These results point out that OsPUB15 acts as a positive regulator of oxidative stress tolerance [130].

Another oxidative stress-related example is the rice STRESS-RELATED RING FINGER PROTEIN 1 (OsSRFP1) [128]. Although OsSRFP1 transcript levels are induced under $\mathrm{H}_{2} \mathrm{O}_{2}$ treatment, transgenic plants constitutively overexpressing OsSRFP1 have reduced oxidative stress tolerance, compared to the wild type. OsSRFP1 knockdowns through RNA interference (RNAi) exhibited an enhanced tolerance towards $\mathrm{H}_{2} \mathrm{O}_{2}$ [128]. Additionally, the RNAi plants had higher levels of both antioxidant enzyme activity and proline pools, indicating that OsSRFP1 serves as a negative regulator of ROS tolerance [128].

Finally, a negative regulator of oxidative stress is the apple (Malus domestica) MYB30INTERACTING E3 LIGASE 1 (MdMIEL1) [160]. Expression levels of MdMIEL1 are upregulated under $\mathrm{H}_{2} \mathrm{O}_{2}$ treatment. Both transgenic Arabidopsis and apple calli that overexpress MdMIEL1 displayed a higher level of ROS accumulation along with increased $\mathrm{H}_{2} \mathrm{O}_{2}$ sensitivity [160]. The mechanism of how MdMIEL affects oxidative stress, and its targets, are still unknown [160].

As climate change increases the abiotic stressors that negatively impact plants, oxidative stress will become more relevant. There is still a lot of work to be done to identify the E3 ligases and corresponding substrates that are involved in oxidative stress response. Expanded knowledge in this field could be a useful compliment to further improve resilience under primary abiotic challenges.

\section{Temperature Stress}

In both cases, high or low temperatures can lead to heat or cold stress in plants, and may cause cell death $[188,189]$. Heat stress generates ROS, which cause damage to macromolecules such as proteins, fats, and nucleic acids [190,191]. They also alter protein structures and affect the structural integrity of membranes due to lipid peroxidation [191]. Cold stress decreases the activity of various enzymes and reduces the fluidity of the plasma membrane, which in turn affects metabolic and physiological processes in the cell [192,193].

Several E3 ligases have been described as regulators of heat stress (Table 1). In Arabidopsis, the PLANT U-BOX 48 (AtPUB48) functions as a positive regulator of heat stress tolerance. Overexpression of AtPUB 48 was connected with significantly greater expression of thermotolerance-related genes and stimulated heat stress tolerance in transgenic plants during the germination and seedling growth stages [94]. Consequently, atpub48 mutants had lower levels of expression and were hypersensitive to elevated temperatures with significantly decreased germination rates, compared to wild type. This data indicates that AtPUB48 targets transcriptional repressors to allow a proper heat stress response [94].

The Arabidopsis RING-finger E3 ligase PROTEIN WITH THE RING DOMAIN AND TMEMB1 (AtPPRT1) is also described to be involved in thermotolerance regulation [106]. AtPPRT1 transcript levels are increased under heat stress, and atpprt1 null mutants showed 
an increase in ROS levels, along with lower seed germination rates, compared to wild type under heat stress [106]. Conversely, seedlings overexpressing AtPPRT1 became more heat stress tolerant [106], which is likely based on higher expression levels of heat stress-related genes, such as HEAT SHOCK PROTEIN 21 (AtHSP21), HEAT SHOCK TRANSCRIPTION FACTOR A7A (AtHSFA7a), and ZINC-FINGER PROTEIN 12 (AtZAT12), in comparison to wild type [106,194-196]. While these results indicate that AtPPRT1 acts as a positive regulator of thermotolerance, its exact mechanism of action needs further investigation [106] (Figure 6A). In addition to its role in thermotolerance regulation, AtPPRT1 has been reported to be involved in both salt and drought stress tolerances [105,107].
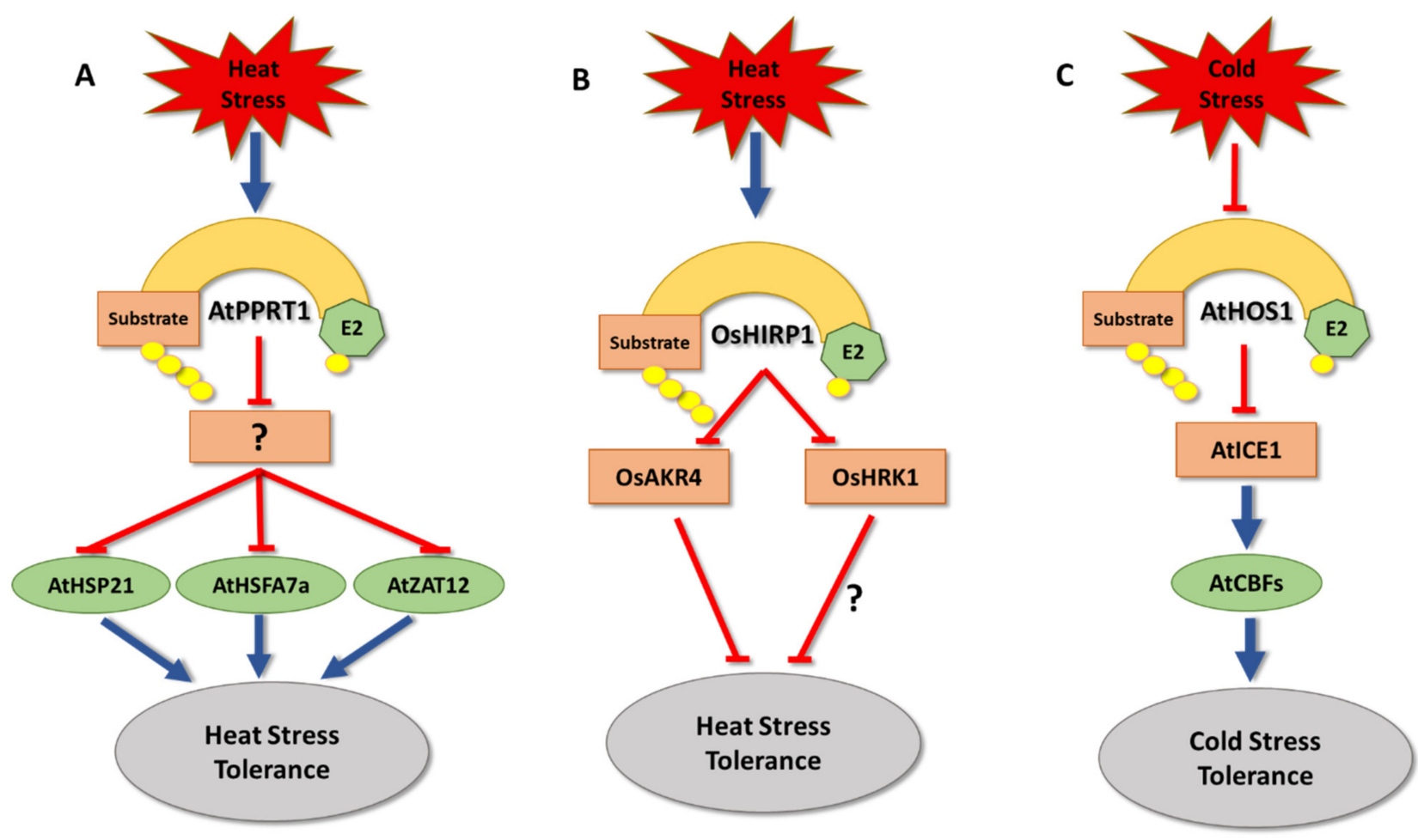

Figure 6. The role of E3 ligases in temperature stress tolerance. (A) Arabidopsis thaliana PROTEIN WITH THE RING DOMAIN AND TMEMB1 (AtPPRT1) positively regulates heat tolerance by triggering the degradation of unknown substrates, which is likely a negative regulator of HEAT SHOCK PROTEIN 21 (AtHSP21), HEAT SHOCK TRANSCRIPTION FACTOR A7A (AtHSFA7a), and ZINCFINGER PROTEIN 12 (AtZAT12). The role of $A$. thaliana HIGH EXPRESSION OF OSMOTICALLY RESPONSIVE GENES 1 (HOS1) in cold stress tolerance. (B) Oryza sativa HEAT-INDUCED RING FINGER PROTEIN 1 (OsHIRP1) positively regulates heat tolerance by triggering degradation of ALDO/KETO REDUCTASE 4 (OsAKR4) and HIRP1-REGULATED KINASE1 (OsHRK1), which is highly likely a negative regulator of heat stress tolerance. (C) Arabidopsis thaliana HIGH EXPRESSION OF OSMOTICALLY RESPONSIVE GENES 1 (HOS1) negatively regulates cold tolerance by triggering degradation of INDUCER OF CBF EXPRESSION 1 (ICE1), which is a positive regulator of C-REPEAT BINDING FACTORS (CBF) transcription factors. CBFs play major roles in cold stress tolerance by promoting transcription of cold tolerance related genes.

Another positive regulator of high temperature stress response is the rice HEATINDUCED RING FINGER PROTEIN 1 (OsHIRP1) [118]. Its expression is increased in plants subjected to higher temperatures, and OsHIRP1 overexpressing plants gained higher seed germination and seedling survival rates under heat stress conditions, compared to wild type, along with increased expression of heat stress-related genes [118]. Proteomic interaction experiments performed to identify potential targets showed that OsHIRP1 targets at least two proteins for degradation, ALDO/KETO REDUCTASE 4 (OsAKR4) and HIRP1-REGULATED KINASE1 (OsHRK1) [118]. OsAKR4 is known to be involved in 
thermotolerance regulation, while the function of OsHRK1 is not yet understood $[197,198]$ (Figure 6B).

On the other hand, several E3 ligases have been identified that play roles in regulating cold stress responses (Table 1). For example, in Arabidopsis and rice HIGH EXPRESSION OF OSMOTICALLY RESPONSIVE GENES 1 (HOS1) acts as a negative regulator of cold stress tolerance $[97,98,132]$ by affecting expression of C-REPEAT BINDING FACTORS (CBF) transcription factors $[97,98,132]$. CBF transcription factors promote expression of genes that carry DEHYDRATION RESPONSIVE ELEMENTS (DRE) in their promoter region [199-201]. Critical for $C B F$ expression is the transcription factor INDUCER OF CBF EXPRESSION 1 (ICE1) [202]. ICE1 has been shown to physically interact with and be ubiquitylated by HOS1, which results in its proteasomal degradation and CBF suppression [98] (Figure 6C).

Similarly in banana (Musa acuminata) the RING finger E3 ligase SEVEN IN ABSENTIA (SINA) regulates the stability of MaICE1 [203]. Both protein interaction and ubiquitination assays showed that SINA marks MaICE1 for proteasomal degradation [203], demonstrating that MaSINA, like HOS1 in Arabidopsis and rice, is a negative regulator of cold stress tolerance in banana.

The overall global temperature has been steadily rising over the last decades. This trend is predicted to continue, leading to warmer springs that can impact germination and seedling development. Understanding E3 ligases that positively regulate heat response, such as AtPPRT1 and OsHIRP1, could offer ideas to protect crops during this critical growth phase.

\section{Heavy Metal Stress}

Proteins are basic components of living cells, and they have several important vital roles such as signaling, regulation, structural support, defense, transport, and movement [204]. Structure is a key aspect for proper protein function, and heavy metals (HMs) are one class of harmful chemicals that can disrupt this by forming sulfhydryl bonds. HMs can also displace the normal metals used as enzymatic cofactors, causing functional loss of enzyme activity [205-207]. Moreover, an elevation of ROS formation has been identified as a result of antioxidative enzymes being inhibited by HMs [208].

HMs are nondegradable inorganic elements with high density and high atomic mass [208]. Some are considered essential, in minimal amounts, for normal plant growth, (e.g., $\mathrm{Cu}^{2+}, \mathrm{Mo}^{4+}, \mathrm{Ni}^{2+}, \mathrm{Se}^{2+}, \mathrm{Co}^{2+}, \mathrm{Zn}^{2+}$ and $\mathrm{Mn}^{2+}$ ), while others have no known benefits to plants (e.g., $\mathrm{Cd}^{2+}, \mathrm{Sb}^{3+}, \mathrm{Cr}^{3+}, \mathrm{As}^{3+}, \mathrm{Pb}^{2+}, \mathrm{Ag}^{1+}$ and $\mathrm{Hg}^{2+}$ ) $[209,210]$. The high-level uptake of heavy metals in general is harmful [211], and in crops it can cause a reduction in yield $[212,213]$. There are several E3 ligases that have been described to be involved in the regulation of HMs stress tolerance (Table 1).

In rice HEAVY METAL INDUCED RING E3 LIGASE 1 (OsHIR1) was described as a positive regulator of HMs tolerance [117]. An upregulation of OsHIR1 transcript levels has been shown under $50 \mu \mathrm{M} \mathrm{Cd}^{2+}$ or $150 \mu \mathrm{M} \mathrm{As}^{3+}$ treatments [117], and Arabidopsis plants overexpressing OsHIR1 displayed reduced sensitivity toward both $\mathrm{Cd}^{2+}$ and $\mathrm{As}^{3+}$ exposure. This was likely due to a lower accumulation of these HMs in roots and shoots compared to wildtype [117]. Moreover, it was demonstrated that OsHIR1 interacted with TONOPLAST INTRINSIC PROTEIN 4;1 (OsTIP4;1) and enhanced its degradation via the 26S proteasome pathway [117]. OsTIP4;1 is an aquaporin protein located in the tonoplast and has a high rate of water and glycerol transport $[214,215]$. Both glycerol and $\mathrm{As}^{3+}$ have the same uptake mechanisms, and they compete for transport by OsTIP4;1, which suggests that OsHIR1 decreased the uptake of $\mathrm{As}^{3+}$ by promoting the degradation of OsTIP4;1 $[117,216]$.

Besides its role as a positive regulator of salt and drought stress in wheat $[139,140]$, the PLANT U-BOX 1 (TaPUB1) was described as a positive regulator for $\mathrm{Cd}^{2+}$ stress tolerance [141] (Figure 7). Under $\mathrm{Cd}^{2+}$ treatment $\left(200 \mu \mathrm{M} \mathrm{CdCl}_{2}\right)$, TaPUB1 overexpression lines exhibited a reduction in $\mathrm{Cd}^{2+}$ accumulation in both roots and shoots and better survival rates and root growth in comparison to wildtype plants. TaPUB1-RNA $i$ lines showed opposite findings [141]. TaPUB1 interacts with IRON-REGULATED TRANSPORTER 1 (TaIRT1) 
and INDOLE-3-ACETIC ACID INDUCIBLE 17 (TaIAA17) and mediates their degradation via the 26S proteasome pathway [141]. TaIRT1 is an iron transporter that facilitates $\mathrm{Cd}^{2+}$ uptake. Its accumulation in the root $[217,218]$ suggests that TaPUB1-triggered degradation of TaIRT1 results in the observed reduced $\mathrm{Cd}^{2+}$ accumulation [141]. TaIAA17 is a transcriptional regulator that functions as a repressor of auxin-inducible gene expression, and a negative regulator of root elongation growth [219]. $\mathrm{Cd}^{2+}$ treatment reduced auxin levels in the plant, stabilized the suppression of auxin signaling by TaIAA17, and reduced root elongation $[220,221]$. This suggests that TaPUB1 counteracts $\mathrm{Cd}^{2+}$-dependent root growth by promoting TaIAA7 degradation [141].

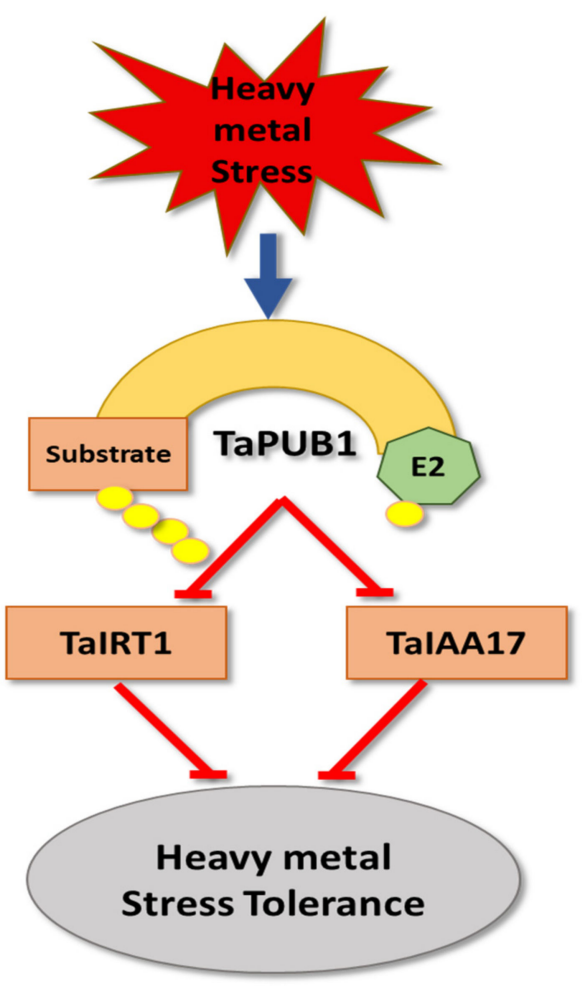

Figure 7. The role of T. aestivum PLANT U-BOX 1 (TaPUB1) in heavy metal (HMs) stress tolerance. TaPUB1 positively regulates HM tolerance by triggering degradation of both IRON-REGULATED TRANSPORTER 1 (TaIRT1) and INDOLE-3-ACETIC ACID INDUCIBLE 17 (TaIAA17), which act as negative regulators of HM stress tolerance.

Because TaPUB1 has been reported as a positive regulator of multiple abiotic stresses (drought, salt, and HMs), it could be a potential candidate for genetic engineering research to produce transgenic plants with a broad range of abiotic stress tolerance traits.

In tomato the REALLY INTERESTING NEW GENE 1 (SIRING1) protein is also critical for $\mathrm{Cd}^{2+}$ tolerance [157]. Tomato transgenic lines that overexpress SIRING1 displayed higher photosynthetic rates and higher chlorophyll levels, compared to wildtype, when treated with $\mathrm{Cd}^{2+}$ [157]. The transgenic lines also showed a reduction in ROS level and overall membrane damage [157]. Moreover, SIRING1 overexpressing plants exhibited a decrease in $\mathrm{Cd}^{2+}$ accumulation in both roots and shoots, indicating a positive role of SIRING1 in controlling $\mathrm{Cd}^{2+}$ tolerance [157].

High levels of HMs in food crops are an especially worrying concern in developing countries [222,223]. In addition to the effects on plant growth, these concentrated HMs are then consumed by people and livestock, which can have unhealthy side effects. Learning more about how E3 ligase activity in plants connected with HM tolerance may help prevent, or at least reduce, the uptake of such contaminants from the soil, providing double benefits for agricultural yield as well as animal and human health. 


\section{Conclusions and Future Perspectives}

Abiotic stress is one of the main negative influences that affects the productivity of crops worldwide. Because plants are sessile organisms, they completely depend on fast responsive regulatory mechanisms to withstand stress, which is represented by the UPP, and the diversity of E3 ligases and their substrates. This review highlighted E3 ligases and how critical they are for abiotic stress tolerance, but it also becomes clear how little is known about the regulatory mechanisms and substrate proteins targeted in order to cope with detrimental situations. For example, in Arabidopsis, one of the first plants fully sequenced, more than 1100 potential E3 ligases have been discovered to date. However, for most, their biological roles are still unknown, and their predicted role as E3 ligases is normally only based on the presence of certain motifs, such as RING or U-box [12,13].

It will be critical in the future to systematically investigate the remaining E3 ligase candidates, whether they are indeed active within the UPP, and to what extent they affect abiotic stress responses. It is expected that this will still require step-by-step analysis of individual E3 ligases using classical gain- and loss-of-function approaches. However, modern technologies that utilize the powers of proteomics and transcriptomics will be needed in the future to effectively unravel the breadth of substrates and the impacts specific E3 ligases have on cellular systems. Specific tools that could be useful include proteinprotein interaction assays that can detect the moderate and weak transient interactions, such as protein microarrays, which support analyzing thousands of proteins at the same time in a single experiment, and provide instant detection of two protein interactions. Both bimolecular fluorescence complementation (BiFC) and split-luciferase assay (Split-LUC) can be used to provide direct information of protein-protein interaction and subcellular localization of the interaction in living plant cells [224]. Such data will help to develop detailed models of abiotic stress responses and clarify the roles that E3 ligases play in plants, which will facilitate the design of novel approaches to generate more stress resilient crops in response to global changes in farming conditions.

Author Contributions: Design, making figures, drafting of the article, R.A.-S.; Drafting of the article, critical revision of the article, S.M.; Conception, supervision, drafting, and critical revision of the article for scientific content, H.H. All authors have read and agreed to the published version of the manuscript.

Funding: This project was supported by the Agriculture and Food Research Initiative competitive grant 2019-67013-29160 of the USDA National Institute of Food and Agriculture (NIFA) to H.H. and Tafila Technical University (TTU) to R.S.

Conflicts of Interest: The authors declare that they have no conflict of interest.

\section{Abbreviations}

$\begin{array}{ll}\text { ABC1P11 } & \text { ABC domain containing protein } \\ \text { AKR4 } & \text { aldo/keto reductase } 4 \\ \text { APX1 } & \text { ascorbate peroxidase } 1 \\ \text { BiFC } & \text { bimolecular fluorescence complementation } \\ \text { BTB/POZ } & \text { broad-complex, tramtrack, and bric-à-brac/poxvirus and zinc finger } \\ \text { CAT } & \text { catalase } \\ \text { CBF } & \text { C-repeat binding factors } \\ \text { CLC 6 } & \text { chloride channel 6 } \\ \text { CRL3 } & \text { cullin3 ring e3 ligases } \\ \text { CRL4 } & \text { cullin4 ring e3 ligases } \\ \text { DOR } & \text { drought tolerance repressor } \\ \text { DRE } & \text { dehydration responsive elements }\end{array}$




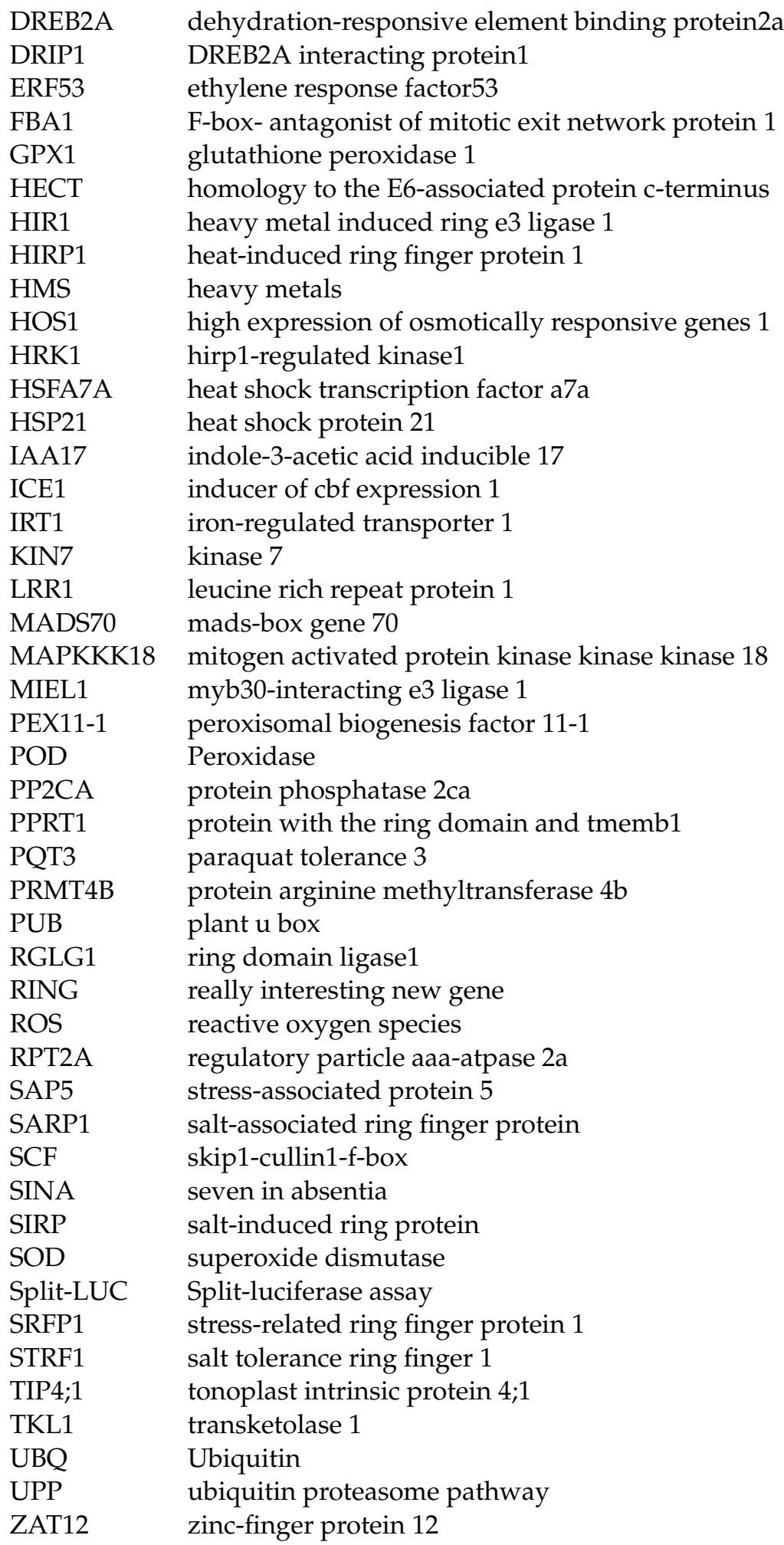

\section{References}

1. Kajla, M.; Yadav, V.K.; Khokhar, J.; Singh, S.; Chhokar, R.; Meena, R.P.; Sharma, R. Increase in wheat production through management of abiotic stresses: A review. J. Appl. Nat. Sci. 2015, 7, 1070-1080. [CrossRef]

2. Iizumi, T.; Shen, Z.; Furuya, J.; Koizumi, T.; Furuhashi, G.; Kim, W.; Nishimori, M. Climate change adaptation cost and residual damage to global crop production. Clim. Res. 2020, 80, 203-218. [CrossRef]

3. He, M.; He, C.Q.; Ding, N.Z. Abiotic Stresses: General Defenses of Land Plants and Chances for Engineering Multistress Tolerance. Front. Plant Sci. 2018, 9, 1771. [CrossRef] 
4. Jmii, S.; Cappadocia, L. Plant SUMO E3 Ligases: Function, Structural Organization, and Connection With DNA. Front. Plant Sci. 2021, 12, 652170. [CrossRef] [PubMed]

5. Lee, J.H.; Kim, W.T. Regulation of abiotic stress signal transduction by E3 ubiquitin ligases in Arabidopsis. Mol. Cells 2011, 31, 201-208. [CrossRef] [PubMed]

6. Chen, L.; Hellmann, H. Plant E3 ligases: Flexible enzymes in a sessile world. Mol. Plant 2013, 6, 1388-1404. [CrossRef]

7. Al-Saharin, R.; Mooney, S.; Hellmann, H. Chapter 11 Plant E3 Ligases as Versatile Tools for Novel Drug Development and Plant Bioengineering. In Protein Degradation with New Chemical Modalities: Successful Strategies in Drug Discovery and Chemical Biology; Weinmann, H., Crews, C., Eds.; The Royal Society of Chemistry: London, UK, 2020; pp. 212-233.

8. Hatfield, P.M.; Gosink, M.M.; Carpenter, T.B.; Vierstra, R.D. The ubiquitin-activating enzyme (E1) gene family in Arabidopsis thaliana. Plant J. Cell Mol. Biol. 1997, 11, 213-226. [CrossRef]

9. Bej, S.; Neeraja, C.N.; Kanth, K.T.; Suman, K.; Barbadikar, K.M.; Voleti, S.R. Correlation of expressional pattern of Ubiquitin activating gene with grain Fe content in rice. Oryza 2020, 57, 251-259. [CrossRef]

10. E, Z.; Zhang, Y.; Li, T.; Wang, L.; Zhao, H. Characterization of the Ubiquitin-Conjugating Enzyme Gene Family in Rice and Evaluation of Expression Profiles under Abiotic Stresses and Hormone Treatments. PLoS ONE 2015, 10, e0122621. [CrossRef]

11. Kraft, E.; Stone, S.L.; Ma, L.; Su, N.; Gao, Y.; Lau, O.S.; Deng, X.W.; Callis, J. Genome analysis and functional characterization of the E2 and RING-type E3 ligase ubiquitination enzymes of Arabidopsis. Plant Physiol. 2005, 139, 1597-1611. [CrossRef]

12. Mazzucotelli, E.; Belloni, S.; Marone, D.; de Leonardis, A.; Guerra, D.; di Fonzo, N.; Cattivelli, L.; Mastrangelo, A. The e3 ubiquitin ligase gene family in plants: Regulation by degradation. Curr. Genom. 2006, 7, 509-522. [CrossRef] [PubMed]

13. Du, Z.; Zhou, X.; Li, L.; Su, Z. plantsUPS: A database of plants' Ubiquitin Proteasome System. BMC Genom. 2009, 10, 227. [CrossRef] [PubMed]

14. Hellmann, H.; Hobbie, L.; Chapman, A.; Dharmasiri, S.; Dharmasiri, N.; del Pozo, C.; Reinhardt, D.; Estelle, M. Arabidopsis AXR6 encodes CUL1 implicating SCF E3 ligases in auxin regulation of embryogenesis. EMBO J. 2003, 22, 3314-3325. [CrossRef]

15. Hotton, S.K.; Callis, J. Regulation of cullin RING ligases. Annu. Rev. Plant Biol. 2008, 59, 467-489. [CrossRef] [PubMed]

16. Choi, C.M.; Gray, W.M.; Mooney, S.; Hellmann, H. Composition, roles, and regulation of cullin-based ubiquitin e3 ligases. Arab. Book 2014, 12, e0175. [CrossRef]

17. del Pozo, J.C.; Estelle, M. F-box proteins and protein degradation: An emerging theme in cellular regulation. Plant Mol. Biol. 2000, 44, 123-128. [CrossRef]

18. Craig, K.L.; Tyers, M. The F-box: A new motif for ubiquitin dependent proteolysis in cell cycle regulation and signal transduction. Prog. Biophys. Mol. Biol. 1999, 72, 299-328. [CrossRef]

19. Pham, V.N.; Kathare, P.K.; Huq, E. Phytochromes and Phytochrome Interacting Factors. Plant Physiol. 2018, 176, 1025-1038. [CrossRef]

20. Salehin, M.; Bagchi, R.; Estelle, M. SCFTIR1/AFB-based auxin perception: Mechanism and role in plant growth and development. Plant Cell 2015, 27, 9-19. [CrossRef]

21. Jiang, L.; Liu, X.; Xiong, G.; Liu, H.; Chen, F.; Wang, L.; Meng, X.; Liu, G.; Yu, H.; Yuan, Y.; et al. DWARF 53 acts as a repressor of strigolactone signalling in rice. Nature 2013, 504, 401-405. [CrossRef] [PubMed]

22. Gusti, A.; Baumberger, N.; Nowack, M.; Pusch, S.; Eisler, H.; Potuschak, T.; de Veylder, L.; Schnittger, A.; Genschik, P. The Arabidopsis thaliana F-box protein FBL17 is essential for progression through the second mitosis during pollen development. PLoS ONE 2009, 4, e4780. [CrossRef] [PubMed]

23. Dohmann, E.M.; Levesque, M.P.; Isono, E.; Schmid, M.; Schwechheimer, C. Auxin responses in mutants of the Arabidopsis Constitutive Photomorphogenic9 signalosome. Plant Physiol. 2008, 147, 1369-1379. [CrossRef] [PubMed]

24. Chung, H.S.; Koo, A.J.; Gao, X.; Jayanty, S.; Thines, B.; Jones, A.D.; Howe, G.A. Regulation and function of Arabidopsis Jasmonate ZIM-domain genes in response to wounding and herbivory. Plant Physiol. 2008, 146, 952-964. [CrossRef] [PubMed]

25. Thines, B.; Katsir, L.; Melotto, M.; Niu, Y.; Mandaokar, A.; Liu, G.; Nomura, K.; He, S.Y.; Howe, G.A.; Browse, J. JAZ repressor proteins are targets of the SCF(COI1) complex during jasmonate signalling. Nature 2007, 448, 661-665. [CrossRef]

26. Han, L.; Mason, M.; Risseeuw, E.P.; Crosby, W.L.; Somers, D.E. Formation of an SCF(ZTL) complex is required for proper regulation of circadian timing. Plant J. Cell Mol. Biol. 2004, 40, 291-301. [CrossRef]

27. McGinnis, K.M.; Thomas, S.G.; Soule, J.D.; Strader, L.C.; Zale, J.M.; Sun, T.P.; Steber, C.M. The Arabidopsis SLEEPY1 gene encodes a putative F-box subunit of an SCF E3 ubiquitin ligase. Plant Cell 2003, 15, 1120-1130. [CrossRef]

28. Abd-Hamid, N.-A.; Ahmad-Fauzi, M.-I.; Zainal, Z.; Ismail, I. Diverse and dynamic roles of F-box proteins in plant biology. Planta 2020, 251, 68. [CrossRef]

29. Nguyen, K.M.; Busino, L. The biology of F-box proteins: The SCF family of E3 ubiquitin ligases. In Cullin-RING Ligases Protein Neddylation; Springer: Singapore, 2020; Volume 1217, pp. 111-122.

30. Gingerich, D.J.; Gagne, J.M.; Salter, D.W.; Hellmann, H.; Estelle, M.; Ma, L.; Vierstra, R.D. Cullins 3a and 3b assemble with members of the broad complex/tramtrack/bric-a-brac (BTB) protein family to form essential ubiquitin-protein ligases (E3s) in Arabidopsis. J. Biol. Chem. 2005, 280, 18810-18821. [CrossRef]

31. Weber, H.; Bernhardt, A.; Dieterle, M.; Hano, P.; Mutlu, A.; Estelle, M.; Genschik, P.; Hellmann, H. Arabidopsis AtCUL3a and AtCUL3b form complexes with members of the BTB/POZ-MATH protein family. Plant Physiol. 2005, 137, 83-93. [CrossRef]

32. Juranic, M.; Dresselhaus, T. Phylogenetic analysis of the expansion of the MATH-BTB gene family in the grasses. Plant Signal. Behav. 2014, 9, e28242. [CrossRef] 
33. Gingerich, D.J.; Hanada, K.; Shiu, S.H.; Vierstra, R.D. Large-scale, lineage-specific expansion of a bric-a-brac/tramtrack/broad complex ubiquitin-ligase gene family in rice. Plant Cell 2007, 19, 2329-2348. [CrossRef] [PubMed]

34. Stogios, P.J.; Downs, G.S.; Jauhal, J.J.; Nandra, S.K.; Prive, G.G. Sequence and structural analysis of BTB domain proteins. Genome Biol. 2005, 6, R82. [CrossRef] [PubMed]

35. Chico, J.M.; Lechner, E.; Fernandez-Barbero, G.; Canibano, E.; Garcia-Casado, G.; Franco-Zorrilla, J.M.; Hammann, P.; Zamarreno, A.M.; Garcia-Mina, J.M.; Rubio, V.; et al. CUL3(BPM) E3 ubiquitin ligases regulate MYC2, MYC3, and MYC4 stability and JA responses. Proc. Natl. Acad. Sci. USA 2020, 117, 6205-6215. [CrossRef] [PubMed]

36. Mooney, S.; Al-Saharin, R.; Choi, C.M.; Tucker, K.; Beathard, C.; Hellmann, H.A. Characterization of Brassica rapa RAP2.4-Related Proteins in Stress Response and as CUL3-Dependent E3 Ligase Substrates. Cells 2019, 8, 336. [CrossRef]

37. Julian, J.; Coego, A.; Lozano-Juste, J.; Lechner, E.; Wu, Q.; Zhang, X.; Merilo, E.; Belda-Palazon, B.; Park, S.Y.; Cutler, S.R.; et al The MATH-BTB BPM3 and BPM5 subunits of Cullin3-RING E3 ubiquitin ligases target PP2CA and other clade A PP2Cs for degradation. Proc. Natl. Acad. Sci. USA 2019, 116, 15725-15734. [CrossRef]

38. Morimoto, K.; Ohama, N.; Kidokoro, S.; Mizoi, J.; Takahashi, F.; Todaka, D.; Mogami, J.; Sato, H.; Qin, F.; Kim, J.S.; et al BPM-CUL3 E3 ligase modulates thermotolerance by facilitating negative regulatory domain-mediated degradation of DREB2A in Arabidopsis. Proc. Natl. Acad. Sci. USA 2017, 114, E8528-E8536. [CrossRef]

39. Chen, L.; Bernhardt, A.; Lee, J.; Hellmann, H. Identification of Arabidopsis MYB56 as a novel substrate for CRL3(BPM) E3 ligases Mol. Plant 2015, 8, 242-250. [CrossRef]

40. Chen, L.; Lee, J.H.; Weber, H.; Tohge, T.; Witt, S.; Roje, S.; Fernie, A.R.; Hellmann, H. Arabidopsis BPM proteins function as substrate adaptors to a cullin3-based E3 ligase to affect fatty acid metabolism in plants. Plant Cell 2013, 25, 2253-2264. [CrossRef]

41. Weber, H.; Hellmann, H. Arabidopsis thaliana BTB/POZ-MATH proteins interact with members of the ERF/AP2 transcription factor family. FEBS J. 2009, 276, 6624-6635. [CrossRef]

42. Figueroa, P.; Gusmaroli, G.; Serino, G.; Habashi, J.; Ma, L.; Shen, Y.; Feng, S.; Bostick, M.; Callis, J.; Hellmann, H.; et al. Arabidopsis has two redundant Cullin3 proteins that are essential for embryo development and that interact with RBX1 and BTB proteins to form multisubunit E3 ubiquitin ligase complexes in vivo. Plant Cell 2005, 17, 1180-1195. [CrossRef]

43. Beathard, C.; Mooney, S.; Al-Saharin, R.; Goyer, A.; Hellmann, H. Characterization of Arabidopsis thaliana R2R3 S23 MYB Transcription Factors as Novel Targets of the Ubiquitin Proteasome-Pathway and Regulators of Salt Stress and Abscisic Acid Response. Front. Plant Sci. 2021, 12, 629208. [CrossRef] [PubMed]

44. Biedermann, S.; Hellmann, H. WD40 and CUL4-based E3 ligases: Lubricating all aspects of life. Trends Plant Sci. 2011, 16, 38-46. [CrossRef] [PubMed]

45. Bian, S.; Li, X.; Mainali, H.; Chen, L.; Dhaubhadel, S. Genome-wide analysis of DWD proteins in soybean (Glycine max): Significance of Gm08DWD and GmMYB176 interaction in isoflavonoid biosynthesis. PLoS ONE 2017, 12, e0178947. [CrossRef] [PubMed]

46. Lee, J.H.; Terzaghi, W.; Gusmaroli, G.; Charron, J.B.; Yoon, H.J.; Chen, H.; He, Y.J.; Xiong, Y.; Deng, X.W. Characterization of Arabidopsis and rice DWD proteins and their roles as substrate receptors for CUL4-RING E3 ubiquitin ligases. Plant Cell 2008, 20, 152-167. [CrossRef]

47. Li, D.; Zhang, L.; Li, X.; Kong, X.; Wang, X.; Li, Y.; Liu, Z.; Wang, J.; Li, X.; Yang, Y. AtRAE1 is involved in degradation of ABA receptor RCAR1 and negatively regulates ABA signalling in Arabidopsis. Plant Cell Environ. 2018, 41, 231-244. [CrossRef]

48. Chen, H.; Huang, X.; Gusmaroli, G.; Terzaghi, W.; Lau, O.S.; Yanagawa, Y.; Zhang, Y.; Li, J.; Lee, J.H.; Zhu, D.; et al. Arabidopsis CULLIN4-damaged DNA binding protein 1 interacts with CONSTITUTIVELY PHOTOMORPHOGENIC1-SUPPRESSOR OF PHYA complexes to regulate photomorphogenesis and flowering time. Plant Cell 2010, 22, 108-123. [CrossRef]

49. Biedermann, S.; Hellmann, H. The DDB1a interacting proteins ATCSA-1 and DDB2 are critical factors for UV-B tolerance and genomic integrity in Arabidopsis thaliana. Plant J. Cell Mol. Biol. 2010, 62, 404-415. [CrossRef]

50. Saleme, M.D.L.S.; Andrade, I.R.; Eloy, N.B. The Role of Anaphase-Promoting Complex/Cyclosome (APC/C) in Plant Reproduction. Front. Plant Sci. 2021, 12, 269. [CrossRef]

51. Volpe, M.; Levinton, N.; Rosenstein, N.; Prag, G.; Ben-Aroya, S. Regulation of the anaphase promoting complex/cyclosome by the degradation of its unassembled catalytic subunit, Apc11. FASEB J. 2019, 33, 9752-9761. [CrossRef]

52. Jimenez-Lopez, D.; Munoz-Belman, F.; Gonzalez-Prieto, J.M.; Aguilar-Hernandez, V.; Guzman, P. Repertoire of plant RING E3 ubiquitin ligases revisited: New groups counting gene families and single genes. PLoS ONE 2018, 13, e0203442. [CrossRef]

53. Ohi, M.D.; Vander Kooi, C.W.; Rosenberg, J.A.; Chazin, W.J.; Gould, K.L. Structural insights into the U-box, a domain associated with multi-ubiquitination. Nat. Struct. Biol. 2003, 10, 250-255. [CrossRef] [PubMed]

54. Kim, M.S.; Kang, K.K.; Cho, Y.G. Molecular and Functional Analysis of U-box E3 Ubiquitin Ligase Gene Family in Rice (Oryzasativa). Int. J. Mol. Sci. 2021, 22, 12088. [CrossRef] [PubMed]

55. Wang, C.; Song, B.; Dai, Y.; Zhang, S.; Huang, X. Genome-wide identification and functional analysis of U-box E3 ubiquitin ligases gene family related to drought stress response in Chinese white pear (Pyrus bretschneideri). BMC Plant Biol. 2021, 21, 235. [CrossRef] [PubMed]

56. Kim, D.Y.; Lee, Y.J.; Hong, M.J.; Kim, J.H.; Seo, Y.W. Genome Wide Analysis of U-Box E3 Ubiquitin Ligases in Wheat (Triticum aestioum L.). Int. J. Mol. Sci. 2021, 22, 2699. [CrossRef]

57. Yee, D.; Goring, D.R. The diversity of plant U-box E3 ubiquitin ligases: From upstream activators to downstream target substrates. J. Exp. Bot. 2009, 60, 1109-1121. [CrossRef] [PubMed] 
58. Wang, N.; Xing, Y.; Lou, Q.; Feng, P.; Liu, S.; Zhu, M.; Yin, W.; Fang, S.; Lin, Y.; Zhang, T.; et al. Dwarf and short grain 1, encoding a putative U-box protein regulates cell division and elongation in rice. J. Plant Physiol. 2017, 209, 84-94. [CrossRef]

59. Wang, Y.; Wu, Y.; Yu, B.; Yin, Z.; Xia, Y. Extra-Large G Proteins Interact with E3 Ligases PUB4 and PUB2 and Function in Cytokinin and Developmental Processes. Plant Physiol. 2017, 173, 1235-1246. [CrossRef]

60. Zhang, Y.; Xia, G.; Zhu, Q. Conserved and Unique Roles of Chaperone-Dependent E3 Ubiquitin Ligase CHIP in Plants. Front. Plant Sci. 2021, 12, 699756. [CrossRef]

61. Lin, Y.; Hu, Q.; Zhou, J.; Yin, W.; Yao, D.; Shao, Y.; Zhao, Y.; Guo, B.; Xia, Y.; Chen, Q.; et al. Phytophthora sojae effector Avr1d functions as an E2 competitor and inhibits ubiquitination activity of GmPUB13 to facilitate infection. Proc. Natl. Acad. Sci. USA 2021, 118, 10. [CrossRef]

62. Yu, Y.; Meng, X.; Guo, D.; Yang, S.; Zhang, G.; Liang, Z. Grapevine U-Box E3 Ubiquitin Ligase VlPUB38 Negatively Regulates Fruit Ripening by Facilitating Abscisic-Aldehyde Oxidase Degradation. Plant Cell Physiol. 2021, 61, 2043-2054. [CrossRef]

63. Li, J.; Zhang, Y.; Gao, Z.; Xu, X.; Wang, Y.; Lin, Y.; Ye, P.; Huang, T. Plant U-box E3 ligases PUB25 and PUB26 control organ growth in Arabidopsis. New Phytol. 2021, 229, 403-413. [CrossRef] [PubMed]

64. Somssich, M.; Je, B.I.; Simon, R.; Jackson, D. Clavata-Wuschel signaling in the shoot meristem. Development 2016, 143, 3238-3248. [CrossRef] [PubMed]

65. Seo, D.H.; Lee, A.; Yu, S.G.; Cui, L.H.; Min, H.J.; Lee, S.E.; Cho, N.H.; Kim, S.; Bae, H.; Kim, W.T. OsPUB41, a U-box E3 ubiquitin ligase, acts as a negative regulator of drought stress response in rice (Oryza sativa L.). Plant Mol. Biol. 2021, 106, 463-477. [CrossRef] [PubMed]

66. Zhao, J.; Zhao, L.; Zhang, M.; Zafar, S.A.; Fang, J.; Li, M.; Zhang, W.; Li, X. Arabidopsis E3 ubiquitin ligases PUB22 and PUB23 negatively regulate drought tolerance by targeting ABA receptor PYL9 for degradation. Int. J. Mol. Sci. 2017, 18, 1841. [CrossRef] [PubMed]

67. Chen, X.; Wang, T.; Rehman, A.U.; Wang, Y.; Qi, J.; Li, Z.; Song, C.; Wang, B.; Yang, S.; Gong, Z. Arabidopsis U-box E3 ubiquitin ligase PUB11 negatively regulates drought tolerance by degrading the receptor-like protein kinases LRR1 and KIN7. J. Integr. Plant Biol. 2021, 63, 494-509. [CrossRef]

68. Alam, I.; Cui, D.L.; Batool, K.; Yang, Y.Q.; Lu, Y.H. Comprehensive Genomic Survey, Characterization and Expression Analysis of the HECT Gene Family in Brassica rapa L. and Brassica oleracea L. Genes 2019, 10, 400. [CrossRef]

69. Li, Y.; Zhai, L.; Fan, J.; Ren, J.; Gong, W.; Wang, X.; Huang, J. Genome-wide identification, phylogenetic and expression analysis of the maize HECT E3 ubiquitin ligase genes. Genetica 2019, 147, 391-400. [CrossRef]

70. Lan, W.; Ma, W.; Miao, Y. Role of HECT ubiquitin protein ligases in Arabidopsis thaliana. J Plant SSci Phytopathol. 2018, 2, 20-30. [CrossRef]

71. Kamadurai, H.B.; Qiu, Y.; Deng, A.; Harrison, J.S.; Macdonald, C.; Actis, M.; Rodrigues, P.; Miller, D.J.; Souphron, J.; Lewis, S.M.; et al. Mechanism of ubiquitin ligation and lysine prioritization by a HECT E3. Elife 2013, 2, e00828. [CrossRef]

72. Furniss, J.J.; Grey, H.; Wang, Z.; Nomoto, M.; Jackson, L.; Tada, Y.; Spoel, S.H. Proteasome-associated HECT-type ubiquitin ligase activity is required for plant immunity. PLoS ONE Pathog. 2018, 14, e1007447. [CrossRef]

73. Bray, E.A. Plant responses to water deficit. Trends Plant Sci. 1997, 2, 48-54. [CrossRef]

74. Hussain, S.; Hussain, S.; Qadir, T.; Khaliq, A.; Ashraf, U.; Parveen, A.; Saqib, M.; Rafiq, M. Drought stress in plants: An overview on implications, tolerance mechanisms and agronomic mitigation strategies. Plant Sci. Today 2019, 6, 389-402. [CrossRef]

75. Jaleel, C.A.; Manivannan, P.; Wahid, A.; Farooq, M.; Al-Juburi, H.J.; Somasundaram, R.; Panneerselvam, R. Drought stress in plants: A review on morphological characteristics and pigments composition. Int. J. Agric. Biol 2009, 11, 100-105.

76. Cheng, M.-C.; Hsieh, E.-J.; Chen, J.-H.; Chen, H.-Y.; Lin, T.-P. Arabidopsis RGLG2, functioning as a RING E3 ligase, interacts with AtERF53 and negatively regulates the plant drought stress response. Plant Physiol. 2012, 158, 363-375. [CrossRef] [PubMed]

77. Zhang, Y.E.; Xu, W.; Li, Z.; Deng, X.W.; Wu, W.; Xue, Y. F-box protein DOR functions as a novel inhibitory factor for abscisic acid-induced stomatal closure under drought stress in Arabidopsis. Plant Physiol. 2008, 148, 2121-2133. [CrossRef] [PubMed]

78. Kim, H.; Song, E.; Kim, Y.; Choi, E.; Hwang, J.; Lee, J.H. Loss-of-function of Arabidopsis F-BOX PROTEIN HYPERSENSITIVE TO ABA 1 enhances drought tolerance and delays germination. Physiol. Plant. 2021, 173, 2376-2389. [CrossRef] [PubMed]

79. Li, B.W.; Gao, S.; Yang, Z.M.; Song, J.B. The F-box E3 ubiquitin ligase AtSDR is involved in salt and drought stress responses in Arabidopsis. Gene 2022, 809, 146011. [CrossRef]

80. Kang, M.; Fokar, M.; Abdelmageed, H.; Allen, R.D. Arabidopsis SAP5 functions as a positive regulator of stress responses and exhibits E3 ubiquitin ligase activity. Plant Mol. Biol. 2011, 75, 451-466. [CrossRef] [PubMed]

81. Ryu, M.Y.; Cho, S.K.; Kim, W.T. The Arabidopsis C3H2C3-type RING E3 ubiquitin ligase AtAIRP1 is a positive regulator of an abscisic acid-dependent response to drought stress. Plant Physiol. 2010, 154, 1983-1997. [CrossRef] [PubMed]

82. Cho, S.K.; Ryu, M.Y.; Seo, D.H.; Kang, B.G.; Kim, W.T. The Arabidopsis RING E3 ubiquitin ligase AtAIRP2 plays combinatory roles with AtAIRP1 in abscisic acid-mediated drought stress responses. Plant Physiol. 2011, 157, 2240-2257. [CrossRef]

83. Kim, J.H.; Kim, W.T. The Arabidopsis RING E3 ubiquitin ligase AtAIRP3/LOG2 participates in positive regulation of high-salt and drought stress responses. Plant Physiol. 2013, 162, 1733-1749. [CrossRef] [PubMed]

84. Qin, X.; Huang, S.; Liu, Y.; Bian, M.; Shi, W.; Zuo, Z.; Yang, Z. Overexpression of A RING finger ubiquitin ligase gene AtATRF1 enhances aluminium tolerance in Arabidopsis thaliana. J. Plant Biol. 2017, 60, 66-74. [CrossRef]

85. Gao, W.; Liu, W.; Zhao, M.; Li, W.-X. NERF encodes a RING E3 ligase important for drought resistance and enhances the expression of its antisense gene NFYA5 in Arabidopsis. Nucleic Acids Res. 2015, 43, 607-617. [CrossRef] [PubMed] 
86. Li, J.; Han, Y.; Zhao, Q.; Li, C.; Xie, Q.; Chong, K.; Xu, Y. The E3 ligase AtRDUF1 positively regulates salt stress responses in Arabidopsis thaliana. PLOS ONE 2013, 8, e71078.

87. Luo, C.; Cai, X.-T.; Du, J.; Zhao, T.-L.; Wang, P.-F.; Zhao, P.-X.; Liu, R.; Xie, Q.; Cao, X.-F.; Xiang, C.-B. Paraquat Tolerance3 is an E3 ligase and acts as a negative regulator of oxidative stress response. bioRxiv 2016, 1, 040543.

88. Li, Y.; Jia, F.; Yu, Y.; Luo, L.; Huang, J.; Yang, G.; Wu, C.; Zheng, C. The SCF E3 ligase AtPP2-B11 plays a negative role in response to drought stress in Arabidopsis. Plant Mol. Biol. Rep. 2014, 32, 943-956. [CrossRef]

89. Jia, F.; Wang, C.; Huang, J.; Yang, G.; Wu, C.; Zheng, C. SCF E3 ligase PP2-B11 plays a positive role in response to salt stress in Arabidopsis. J. Exp. Bot. 2015, 66, 4683-4697. [CrossRef]

90. Liu, Y.-C.; Wu, Y.-R.; Huang, X.-H.; Sun, J.; Xie, Q. AtPUB19, a U-box E3 ubiquitin ligase, negatively regulates abscisic acid and drought responses in Arabidopsis thaliana. Mol. Plant 2011, 4, 938-946. [CrossRef]

91. Hwang, J.H.; Seo, D.H.; Kang, B.G.; Kwak, J.M.; Kim, W.T. Suppression of Arabidopsis AtPUB30 resulted in increased tolerance to salt stress during germination. Plant Cell Rep. 2015, 34, 277-289. [CrossRef]

92. Adler, G.; Mishra, A.K.; Maymon, T.; Raveh, D.; Bar-Zvi, D. Overexpression of Arabidopsis ubiquitin ligase AtPUB46 enhances tolerance to drought and oxidative stress. Plant Sci. 2018, 276, 220-228. [CrossRef]

93. Adler, G.; Konrad, Z.; Zamir, L.; Mishra, A.K.; Raveh, D.; Bar-Zvi, D. The Arabidopsis paralogs, PUB46 and PUB48, encoding U-box E3 ubiquitin ligases, are essential for plant response to drought stress. BMC Plant Biol. 2017, 17, 8. [CrossRef] [PubMed]

94. Peng, L.; Wan, X.; Huang, K.; Pei, L.; Xiong, J.; Li, X.; Wang, J. AtPUB48 E3 ligase plays a crucial role in the thermotolerance of Arabidopsis. Biochem. Biophys. Res. Commun. 2019, 509, 281-286. [CrossRef] [PubMed]

95. Zhang, Y.; Yang, C.; Li, Y.; Zheng, N.; Chen, H.; Zhao, Q.; Gao, T.; Guo, H.; Xie, Q. SDIR1 is a RING finger E3 ligase that positively regulates stress-responsive abscisic acid signaling in Arabidopsis. Plant Cell 2007, 19, 1912-1929. [CrossRef] [PubMed]

96. Ye, Q.; Wang, H.; Su, T.; Wu, W.-H.; Chen, Y.-F. The ubiquitin E3 ligase PRU1 regulates WRKY6 degradation to modulate phosphate homeostasis in response to low-pi stress in Arabidopsis. Plant Cell 2018, 30, 1062-1076. [CrossRef]

97. Lee, H.; Xiong, L.; Gong, Z.; Ishitani, M.; Stevenson, B.; Zhu, J.-K. The Arabidopsis HOS1 gene negatively regulates cold signal transduction and encodes a RING finger protein that displays cold-regulated nucleo-cytoplasmic partitioning. Genes Dev. 2001, 15, 912-924. [CrossRef]

98. Dong, C.-H.; Agarwal, M.; Zhang, Y.; Xie, Q.; Zhu, J.-K. The negative regulator of plant cold responses, HOS1, is a RING E3 ligase that mediates the ubiquitination and degradation of ICE1. Proc. Natl. Acad. Sci. USA 2006, 103, 8281-8286. [CrossRef]

99. Kim, S.J.; Ryu, M.Y.; Kim, W.T. Suppression of Arabidopsis RING-DUF1117 E3 ubiquitin ligases, AtRDUF1 and AtRDUF2, reduces tolerance to ABA-mediated drought stress. Biochem. Biophys. Res. Commun. 2012, 420, 141-147. [CrossRef]

100. Kim, S.J.; Kim, W.T. Suppression of Arabidopsis RING E3 ubiquitin ligase AtATL78 increases tolerance to cold stress and decreases tolerance to drought stress. FEBS Lett. 2013, 587, 2584-2590. [CrossRef]

101. Yang, R.; Wang, T.; Shi, W.; Li, S.; Liu, Z.; Wang, J.; Yang, Y. E3 ubiquitin ligase ATL61 acts as a positive regulator in abscisic acid mediated drought response in Arabidopsis. Biochem. Biophys. Res. Commun. 2020, 528, 292-298. [CrossRef]

102. Tian, M.; Lou, L.; Liu, L.; Yu, F.; Zhao, Q.; Zhang, H.; Wu, Y.; Tang, S.; Xia, R.; Zhu, B. The RING finger E3 ligase STRF1 is involved in membrane trafficking and modulates salt-stress response in Arabidopsis thaliana. Plant J. 2015, 82, 81-92. [CrossRef]

103. Yu, S.G.; Kim, J.H.; Cho, N.H.; Oh, T.R.; Kim, W.T. Arabidopsis RING E3 ubiquitin ligase JUL1 participates in ABA-mediated microtubule depolymerization, stomatal closure, and tolerance response to drought stress. Plant J. 2020, 103, 824-842. [CrossRef] [PubMed]

104. Liu, B.; Jiang, Y.; Tang, H.; Tong, S.; Lou, S.; Shao, C.; Zhang, J.; Song, Y.; Chen, N.; Bi, H. The ubiquitin E3 ligase SR1 modulates the submergence response by degrading phosphorylated WRKY33 in Arabidopsis. Plant Cell 2021, 33, 1771-1789. [CrossRef] [PubMed]

105. Liu, Y.; Pei, L.; Xiao, S.; Peng, L.; Liu, Z.; Li, X.; Yang, Y.; Wang, J. AtPPRT1 negatively regulates salt stress response in Arabidopsis seedlings. Plant Signal. Behav. 2020, 15, 1732103. [CrossRef] [PubMed]

106. Liu, Y.; Xiao, S.; Sun, H.; Pei, L.; Liu, Y.; Peng, L.; Gao, X.; Wang, J. AtPPRT1, an E3 ubiquitin ligase, enhances the thermotolerance in Arabidopsis. Plants 2020, 9, 1074. [CrossRef] [PubMed]

107. Pei, L.; Peng, L.; Wan, X.; Xiong, J.; Liu, Z.; Li, X.; Yang, Y.; Wang, J. Expression pattern and function analysis of AtPPRT1, a novel negative regulator in ABA and drought stress responses in Arabidopsis. Int. J. Mol. Sci. 2019, 20, 394. [CrossRef]

108. Li, H.; Jiang, H.; Bu, Q.; Zhao, Q.; Sun, J.; Xie, Q.; Li, C. The Arabidopsis RING finger E3 ligase RHA2b acts additively with RHA2a in regulating abscisic acid signaling and drought response. Plant Physiol. 2011, 156, 550-563. [CrossRef]

109. Zheng, Y.; Chen, Z.; Ma, L.; Liao, C. The ubiquitin E3 ligase RHA2b promotes degradation of MYB30 in abscisic acid signaling. Plant Physiol. 2018, 178, 428-440. [CrossRef]

110. Ding, S.; Zhang, B.; Qin, F. Arabidopsis RZFP34/CHYR1, a ubiquitin E3 ligase, regulates stomatal movement and drought tolerance via SnRK2. 6-mediated phosphorylation. Plant Cell 2015, 27, 3228-3244. [CrossRef]

111. Li, Q.; Serio, R.J.; Schofield, A.; Liu, H.; Rasmussen, S.R.; Hofius, D.; Stone, S.L. Arabidopsis RING-type E3 ubiquitin ligase XBAT35. 2 promotes proteasome-dependent degradation of ACD11 to attenuate abiotic stress tolerance. Plant J. 2020, 104, 1712-1723. [CrossRef]

112. Kim, J.H.; Seo, H.U.; Lee, J.E.; Lim, S.D.; Jang, C.S. Heterogeneous Overexpression of Two Oryza sativa Arsenic-Induced RING E3 Ligase4 (OsAIR4. 1 and 4.2) Transcripts Enhances Plant Tolerance to Arsenic Stress. J. Plant Biol. 2021, 1-12. [CrossRef] 
113. Choi, J.; Lee, W.; An, G.; Kim, S.-R. OsCBE1, a Substrate Receptor of Cullin4-Based E3 Ubiquitin Ligase, Functions as a Regulator of Abiotic Stress Response and Productivity in Rice. Int. J. Mol. Sci. 2021, 22, 2487. [CrossRef] [PubMed]

114. Park, G.-G.; Park, J.-J.; Yoon, J.; Yu, S.-N.; An, G. A RING finger E3 ligase gene, Oryza sativa Delayed Seed Germination 1 (OsDSG1), controls seed germination and stress responses in rice. Plant Mol. Biol. 2010, 74, 467-478. [CrossRef] [PubMed]

115. Bae, H.; Kim, S.K.; Cho, S.K.; Kang, B.G.; Kim, W.T. Overexpression of OsRDCP1, a rice RING domain-containing E3 ubiquitin ligase, increased tolerance to drought stress in rice (Oryza sativa L.). Plant Sci. 2011, 180, 775-782. [CrossRef]

116. Ning, Y.; Jantasuriyarat, C.; Zhao, Q.; Zhang, H.; Chen, S.; Liu, J.; Liu, L.; Tang, S.; Park, C.H.; Wang, X. The SINA E3 ligase OsDIS1 negatively regulates drought response in rice. Plant Physiol. 2011, 157, 242-255. [CrossRef] [PubMed]

117. Lim, S.D.; Hwang, J.G.; Han, A.R.; Park, Y.C.; Lee, C.; Ok, Y.S.; Jang, C.S. Positive regulation of rice RING E3 ligase OsHIR1 in arsenic and cadmium uptakes. Plant Mol. Biol. 2014, 85, 365-379. [CrossRef] [PubMed]

118. Kim, J.H.; Lim, S.D.; Jang, C.S. Oryza sativa heat-induced RING finger protein 1 (OsHIRP1) positively regulates plant response to heat stress. Plant Mol. Biol. 2019, 99, 545-559. [CrossRef]

119. Park, Y.C.; Chapagain, S.; Jang, C.S. The microtubule-associated RING finger protein 1 (OsMAR1) acts as a negative regulator for salt-stress response through the regulation of OCPI2 (O. sativa chymotrypsin protease inhibitor 2). Planta 2018, 247, 875-886. [CrossRef]

120. Zeng, D.-E.; Hou, P.; Xiao, F.; Liu, Y. Overexpressing a novel RING-H2 finger protein gene, OsRHP1, enhances drought and salt tolerance in rice (Oryza sativa L.). J. Plant Biol. 2014, 57, 357-365. [CrossRef]

121. Gao, T.; Wu, Y.; Zhang, Y.; Liu, L.; Ning, Y.; Wang, D.; Tong, H.; Chen, S.; Chu, C.; Xie, Q. OsSDIR1 overexpression greatly improves drought tolerance in transgenic rice. Plant Mol. Biol. 2011, 76, 145-156. [CrossRef]

122. Chapagain, S.; Jang, C.S. Heterogeneous overexpression of Oryza sativa salt induced RING Finger protein OsSIRF1 positively regulates salt and osmotic stress in transgenic Arabidopsis. In Proceedings of the Korean Society of Crop Science Conference, Jeju, Korea, 4-7 June 2017; p. 150.

123. Hwang, S.G.; Kim, J.J.; Lim, S.D.; Park, Y.C.; Moon, J.C.; Jang, C.S. Molecular dissection of Oryza sativa salt-induced RING Finger Protein 1 (OsSIRP1): Possible involvement in the sensitivity response to salinity stress. Physiol. Plant. 2016, 158, 168-179. [CrossRef]

124. Chapagain, S.; Park, Y.C.; Kim, J.H.; Jang, C.S. Oryza sativa salt-induced RING E3 ligase 2 (OsSIRP2) acts as a positive regulator of transketolase in plant response to salinity and osmotic stress. Planta 2018, 247, 925-939. [CrossRef] [PubMed]

125. Park, Y.C.; Moon, J.-C.; Chapagain, S.; Oh, D.G.; Kim, J.J.; Jang, C.S. Role of salt-induced RING finger protein 3 (OsSIRP3), a negative regulator of salinity stress response by modulating the level of its target proteins. Environ. Exp. Bot. 2018, 155, 21-30. [CrossRef]

126. Kim, J.H.; Jang, C.S. E3 ligase, the Oryza sativa salt-induced RING finger protein 4 (OsSIRP4), negatively regulates salt stress responses via degradation of the OsPEX11-1 protein. Plant Mol. Biol. 2021, 105, 231-245. [CrossRef]

127. Park, Y.C.; Lim, S.D.; Moon, J.C.; Jang, C.S. A rice really interesting new gene H 2-type E 3 ligase, OsSIRH2-14, enhances salinity tolerance via ubiquitin/26 S proteasome-mediated degradation of salt-related proteins. Plant Cell Environ. 2019, 42, 3061-3076. [CrossRef] [PubMed]

128. Fang, H.; Meng, Q.; Xu, J.; Tang, H.; Tang, S.; Zhang, H.; Huang, J. Knock-down of stress inducible OsSRFP1 encoding an E3 ubiquitin ligase with transcriptional activation activity confers abiotic stress tolerance through enhancing antioxidant protection in rice. Plant Mol. Biol. 2015, 87, 441-458. [CrossRef] [PubMed]

129. Byun, M.Y.; Cui, L.H.; Oh, T.K.; Jung, Y.-J.; Lee, A.; Park, K.Y.; Kang, B.G.; Kim, W.T. Homologous U-box E3 ubiquitin ligases OsPUB2 and OsPUB3 are involved in the positive regulation of low temperature stress response in rice (Oryza sativa L.). Front. Plant Sci. 2017, 8, 16. [CrossRef]

130. Park, J.J.; Yi, J.; Yoon, J.; Cho, L.H.; Ping, J.; Jeong, H.J.; Cho, S.K.; Kim, W.T.; An, G. OsPUB15, an E3 ubiquitin ligase, functions to reduce cellular oxidative stress during seedling establishment. Plant J. 2011, 65, 194-205. [CrossRef]

131. Park, Y.C.; Chapagain, S.; Jang, C.S. A negative regulator in response to salinity in rice: Oryza sativa salt-, ABA-and droughtinduced RING finger protein 1 (OsSADR1). Plant Cell Physiol. 2018, 59, 575-589. [CrossRef]

132. Lourenço, T.; Sapeta, H.; Figueiredo, D.D.; Rodrigues, M.; Cordeiro, A.; Abreu, I.A.; Saibo, N.J.; Oliveira, M.M. Isolation and characterization of rice (Oryza sativa L.) E3-ubiquitin ligase OsHOS1 gene in the modulation of cold stress response. Plant Mol. Biol. 2013, 83, 351-363. [CrossRef]

133. Cui, L.H.; Min, H.J.; Byun, M.Y.; Oh, H.G.; Kim, W.T. OsDIRP1, a putative RING E3 ligase, plays an opposite role in drought and cold stress responses as a negative and positive factor, respectively, in rice (Oryza sativa L.). Front. Plant Sci. 2018, 9 , 1797. [CrossRef]

134. Kim, J.H.; Lim, S.D.; Jang, C.S. Oryza sativa drought-, heat-, and salt-induced RING finger protein 1 (OsDHSRP1) negatively regulates abiotic stress-responsive gene expression. Plant Mol. Biol. 2020, 103, 235-252. [CrossRef] [PubMed]

135. Liu, Y.; Li, L.; Zhang, L.; Lv, Q.; Zhao, Y.; Li, X. Isolation and identification of wheat gene TaDIS1 encoding a RING finger domain protein, which negatively regulates drought stress tolerance in transgenic Arabidopsis. Plant Sci. 2018, 275, 49-59. [CrossRef] [PubMed]

136. Li, Q.; Wang, W.; Wang, W.; Zhang, G.; Liu, Y.; Wang, Y.; Wang, W. Wheat F-box protein gene TaFBA1 is involved in plant tolerance to heat stress. Front. Plant Sci. 2018, 9, 521. [CrossRef] [PubMed] 
137. Zhou, S.; Sun, X.; Yin, S.; Kong, X.; Zhou, S.; Xu, Y.; Luo, Y.; Wang, W. The role of the F-box gene TaFBA1 from wheat (Triticum aestivum L.) in drought tolerance. Plant Physiol. Biochem. 2014, 84, 213-223. [CrossRef] [PubMed]

138. Zhou, S.-M.; Kong, X.-Z.; Kang, H.-H.; Sun, X.-D.; Wang, W. The involvement of wheat F-box protein gene TaFBA1 in the oxidative stress tolerance of plants. PLoS ONE 2015, 10, e0122117. [CrossRef]

139. Wang, W.; Wang, W.; Wu, Y.; Li, Q.; Zhang, G.; Shi, R.; Yang, J.; Wang, Y.; Wang, W. The involvement of wheat U-box E3 ubiquitin ligase TaPUB1 in salt stress tolerance. J. Integr. Plant Biol. 2020, 62, 631-651. [CrossRef]

140. Zhang, G.; Zhang, M.; Zhao, Z.; Ren, Y.; Li, Q.; Wang, W. Wheat TaPUB1 modulates plant drought stress resistance by improving antioxidant capability. Sci. Rep. 2017, 7, 7549. [CrossRef]

141. Zhang, G.; Yang, J.; Zhang, M.; Li, Q.; Wu, Y.; Zhao, X.; Zhang, H.; Wang, Y.; Wu, J.; Wang, W. Wheat TaPUB1 Regulates Cd Uptake and Tolerance by Promoting the Degradation of TaIRT1 and TaIAA17. J. Agric. Food Chem. 2021, 69, 5818-5829. [CrossRef]

142. Li, Q.; Li, B.; Wang, J.; Chang, X.; Mao, X.; Jing, R. TaPUB15, a U-Box E3 ubiquitin ligase gene from wheat, enhances salt tolerance in rice. Food Energy Secur. 2021, 10, e250. [CrossRef]

143. Wu, Y.; Wang, W.; Li, Q.; Zhang, G.; Zhao, X.; Li, G.; Li, Y.; Wang, Y.; Wang, W. The wheat E3 ligase TaPUB26 is a negative regulator in response to salt stress in transgenic Brachypodium distachyon. Plant Sci. 2020, 294, 110441. [CrossRef]

144. Zhang, N.; Yin, Y.; Liu, X.; Tong, S.; Xing, J.; Zhang, Y.; Pudake, R.N.; Izquierdo, E.M.; Peng, H.; Xin, M. The E3 ligase TaSAP5 alters drought stress responses by promoting the degradation of DRIP proteins. Plant Physiol. 2017, 175, 1878-1892. [CrossRef]

145. Agarwal, P.; Khurana, P. TaZnF, a C3HC4 type RING zinc finger protein from Triticum aestivum is involved in dehydration and salinity stress. J. Plant Biochem. Biotechnol. 2020, 29, 395-406. [CrossRef]

146. Joo, H.; Lim, C.W.; Lee, S.C. A pepper RING-type E3 ligase, CaASRF1, plays a positive role in drought tolerance via modulation of CaAIBZ1 stability. Plant J. 2019, 98, 5-18. [CrossRef] [PubMed]

147. Baek, W.; Lim, C.W.; Lee, S.C. Pepper E3 ligase CaAIRE1 promotes ABA sensitivity and drought tolerance by degradation of protein phosphatase CaAITP1. J. Exp. Bot. 2021, 72, 4520-4534. [CrossRef] [PubMed]

148. Park, C.; Lim, C.W.; Baek, W.; Lee, S.C. RING type E3 ligase CaAIR1 in pepper acts in the regulation of ABA signaling and drought stress response. Plant Cell Physiol. 2015, 56, 1808-1819. [CrossRef]

149. Joo, H.; Lim, C.W.; Lee, S.C. Identification and functional expression of the pepper RING type E3 ligase, CaDTR1, involved in drought stress tolerance via ABA-mediated signalling. Sci. Rep. 2016, 6, 30097. [CrossRef]

150. Joo, H.; Lim, C.W.; Lee, S.C. The pepper RING-type E3 ligase, CaATIR1, positively regulates abscisic acid signalling and drought response by modulating the stability of CaATBZ1. Plant Cell Environ. 2020, 43, 1911-1924. [CrossRef]

151. Lim, C.W.; Park, C.; Kim, J.-H.; Joo, H.; Hong, E.; Lee, S.C. Pepper CaREL1, a ubiquitin E3 ligase, regulates drought tolerance via the ABA-signalling pathway. Sci. Rep. 2017, 7, 477. [CrossRef]

152. Joo, H.; Lim, C.W.; Han, S.-W.; Lee, S.C. The pepper RING finger E3 ligase, CaDIR1, regulates the drought stress response via ABA-mediated signaling. Front. Plant Sci. 2017, 8, 690. [CrossRef]

153. Lim, C.W.; Baek, W.; Lee, S.C. The pepper RING-type E3 ligase CaAIRF1 regulates ABA and drought signaling via CaADIP1 protein phosphatase degradation. Plant Physiol. 2017, 173, 2323-2339. [CrossRef]

154. Yang, L.; Wu, L.; Chang, W.; Li, Z.; Miao, M.; Li, Y.; Yang, J.; Liu, Z.; Tan, J. Overexpression of the maize E3 ubiquitin ligase gene ZmAIRP4 enhances drought stress tolerance in Arabidopsis. Plant Physiol. Biochem. 2018, 123, 34-42. [CrossRef] [PubMed]

155. Xia, Z.; Liu, Q.; Wu, J.; Ding, J. ZmRFP1, the putative ortholog of SDIR1, encodes a RING-H2 E3 ubiquitin ligase and responds to drought stress in an ABA-dependent manner in maize. Gene 2012, 495, 146-153. [CrossRef] [PubMed]

156. Liu, Y.; Zhang, X.; Zhu, S.; Zhang, H.; Li, Y.; Zhang, T.; Sun, J. Overexpression of GhSARP1 encoding a E3 ligase from cotton reduce the tolerance to salt in transgenic Arabidopsis. Biochem. Biophys. Res. Commun. 2016, 478, 1491-1496. [CrossRef]

157. Ahammed, G.J.; Li, C.X.; Li, X.; Liu, A.; Chen, S.; Zhou, J. Overexpression of tomato RING E3 ubiquitin ligase gene SIRING1 confers cadmium tolerance by attenuating cadmium accumulation and oxidative stress. Physiol. Plant. 2021, 173, 449-459. [CrossRef]

158. Zhang, R.; Chen, H.; Duan, M.; Zhu, F.; Wen, J.; Dong, J.; Wang, T. Medicago falcata MfSTMIR, an E3 ligase of endoplasmic reticulum-associated degradation, is involved in salt stress response. Plant J. 2019, 98, 680-696. [CrossRef] [PubMed]

159. Qi, S.; Lin, Q.; Zhu, H.; Gao, F.; Zhang, W.; Hua, X. The RING finger E3 ligase SpRing is a positive regulator of salt stress signaling in salt-tolerant wild tomato species. Plant Cell Physiol. 2016, 57, 528-539. [CrossRef]

160. An, J.-P.; Liu, X.; Song, L.-Q.; You, C.-X.; Wang, X.-F.; Hao, Y.-J. Apple RING finger E3 ubiquitin ligase MdMIEL1 negatively regulates salt and oxidative stresses tolerance. J. Plant Biol. 2017, 60, 137-145. [CrossRef]

161. Wang, N.; Liu, Y.; Cong, Y.; Wang, T.; Zhong, X.; Yang, S.; Li, Y.; Gai, J. Genome-wide identification of soybean U-box E3 ubiquitin ligases and roles of GmPUB8 in negative regulation of drought stress response in Arabidopsis. Plant Cell Physiol. 2016, 57, 1189-1209. [CrossRef]

162. Wang, N.; Liu, Y.; Cai, Y.; Tang, J.; Li, Y.; Gai, J. The soybean U-box gene GmPUB6 regulates drought tolerance in Arabidopsis thaliana. Plant Physiol. Biochem. 2020, 155, 284-296. [CrossRef]

163. Yu, J.; Kang, L.; Li, Y.; Wu, C.; Zheng, C.; Liu, P.; Huang, J. RING finger protein RGLG1 and RGLG2 negatively modulate MAPKKK18 mediated drought stress tolerance in Arabidopsis. J. Integr. Plant Biol. 2021, 63, 484-493. [CrossRef]

164. Wu, Q.; Zhang, X.; Peirats-Llobet, M.; Belda-Palazon, B.; Wang, X.; Cui, S.; Yu, X.; Rodriguez, P.L.; An, C. Ubiquitin ligases RGLG1 and RGLG5 regulate abscisic acid signaling by controlling the turnover of phosphatase PP2CA. Plant Cell 2016, 28, 2178-2196. [CrossRef] [PubMed] 
165. Hsieh, E.-J.; Cheng, M.-C.; Lin, T.-P. Functional characterization of an abiotic stress-inducible transcription factor AtERF53 in Arabidopsis thaliana. Plant Mol. Biol. 2013, 82, 223-237. [CrossRef] [PubMed]

166. Tajdel, M.; Mituła, F.; Ludwików, A. Regulation of Arabidopsis MAPKKK18 by ABI1 and SnRK2, components of the ABA signaling pathway. Plant Signal. Behav. 2016, 11, e1139277. [CrossRef]

167. Li, Y.; Cai, H.; Liu, P.; Wang, C.; Gao, H.; Wu, C.; Yan, K.; Zhang, S.; Huang, J.; Zheng, C. Arabidopsis MAPKKK18 positively regulates drought stress resistance via downstream MAPKK3. Biochem. Biophys. Res. Commun. 2017, 484, 292-297. [CrossRef] [PubMed]

168. Nishimura, N.; Sarkeshik, A.; Nito, K.; Park, S.Y.; Wang, A.; Carvalho, P.C.; Lee, S.; Caddell, D.F.; Cutler, S.R.; Chory, J. PYR/PYL/RCAR family members are major in-vivo ABI1 protein phosphatase 2C-interacting proteins in Arabidopsis. Plant J. 2010, 61, 290-299. [CrossRef] [PubMed]

169. Belda-Palazon, B.; Julian, J.; Coego, A.; Wu, Q.; Zhang, X.; Batistic, O.; Alquraishi, S.A.; Kudla, J.; An, C.; Rodriguez, P.L. ABA inhibits myristoylation and induces shuttling of the RGLG 1 E3 ligase to promote nuclear degradation of PP 2 CA. Plant J. 2019, 98, 813-825. [CrossRef] [PubMed]

170. Qin, F.; Sakuma, Y.; Tran, L.-S.P.; Maruyama, K.; Kidokoro, S.; Fujita, Y.; Fujita, M.; Umezawa, T.; Sawano, Y.; Miyazono, K.-i. Arabidopsis DREB2A-interacting proteins function as RING E3 ligases and negatively regulate plant drought stress-responsive gene expression. Plant Cell 2008, 20, 1693-1707. [CrossRef]

171. Sakuma, Y.; Maruyama, K.; Osakabe, Y.; Qin, F.; Seki, M.; Shinozaki, K.; Yamaguchi-Shinozaki, K. Functional analysis of an Arabidopsis transcription factor, DREB2A, involved in drought-responsive gene expression. Plant Cell 2006, 18, 1292-1309. [CrossRef]

172. Wu, F.; Chi, Y.; Jiang, Z.; Xu, Y.; Xie, L.; Huang, F.; Wan, D.; Ni, J.; Yuan, F.; Wu, X. Hydrogen peroxide sensor HPCA1 is an LRR receptor kinase in Arabidopsis. Nature 2020, 578, 577-581. [CrossRef]

173. Isner, J.C.; Begum, A.; Nuehse, T.; Hetherington, A.M.; Maathuis, F.J. KIN7 kinase regulates the vacuolar TPK1 K+ channel during stomatal closure. Curr. Biol. 2018, 28, 466-472. [CrossRef]

174. Um, T.Y.; Lee, S.; Kim, J.-K.; Jang, G.; Do Choi, Y. Chloride Channel 1 promotes drought tolerance in rice, leading to increased grain yield. Plant Biotechnol. Rep. 2018, 12, 283-293. [CrossRef]

175. Chinnusamy, V.; Zhu, J.; Zhu, J.-K. Salt stress signaling and mechanisms of plant salt tolerance. Genet. Eng. 2006, $27,141-177$.

176. Isayenkov, S. Physiological and molecular aspects of salt stress in plants. Cytol. Genet. 2012, 46, 302-318. [CrossRef]

177. Muchate, N.S.; Nikalje, G.C.; Rajurkar, N.S.; Suprasanna, P.; Nikam, T.D. Plant salt stress: Adaptive responses, tolerance mechanism and bioengineering for salt tolerance. Bot. Rev. 2016, 82, 371-406. [CrossRef]

178. Parida, A.K.; Das, A.B. Salt tolerance and salinity effects on plants: A review. Ecotoxicol. Environ. Saf. 2005, 60, 324-349. [CrossRef]

179. Ashraf, M.; Harris, P.J. Photosynthesis under stressful environments: An overview. Photosynthetica 2013, 51, 163-190. [CrossRef]

180. Khozaei, M.; Fisk, S.; Lawson, T.; Gibon, Y.; Sulpice, R.; Stitt, M.; Lefebvre, S.C.; Raines, C.A. Overexpression of plastid transketolase in tobacco results in a thiamine auxotrophic phenotype. Plant Cell 2015, 27, 432-447. [CrossRef]

181. Suzuki, Y.; Kondo, E.; Makino, A. Effects of co-overexpression of the genes of Rubisco and transketolase on photosynthesis in rice. Photosynth. Res. 2017, 131, 281-289. [CrossRef]

182. Hasanuzzaman, M.; Hossain, M.A.; da Silva, J.A.T.; Fujita, M. Plant response and tolerance to abiotic oxidative stress: Antioxidant defense is a key factor. In Crop Stress and its Management: Perspectives and Strategies; Springer: Berlin/Heidelberg, Germany, 2012; pp. 261-315.

183. Xie, X.; He, Z.; Chen, N.; Tang, Z.; Wang, Q.; Cai, Y. The roles of environmental factors in regulation of oxidative stress in plant. BioMed Res. Int. 2019, 2019, 9732325. [CrossRef]

184. Sharma, P.; Dubey, R. Involvement of oxidative stress and role of antioxidative defense system in growing rice seedlings exposed to toxic concentrations of aluminum. Plant Cell Rep. 2007, 26, 2027-2038. [CrossRef]

185. Luo, C.; Cai, X.-T.; Du, J.; Zhao, T.-L.; Wang, P.-F.; Zhao, P.-X.; Liu, R.; Xie, Q.; Cao, X.-F.; Xiang, C.-B. Paraquat Tolerance3 is an E3 ligase that switches off activated oxidative response by targeting histone-modifying Protein Methyltransferase4b. PLoS ONE Genet. 2016, 12, e1006332. [CrossRef] [PubMed]

186. Koussevitzky, S.; Suzuki, N.; Huntington, S.; Armijo, L.; Sha, W.; Cortes, D.; Shulaev, V.; Mittler, R. Ascorbate peroxidase 1 plays a key role in the response of Arabidopsis thaliana to stress combination. J. Biol. Chem. 2008, 283, 34197-34203. [CrossRef] [PubMed]

187. Roxas, V.P.; Lodhi, S.A.; Garrett, D.K.; Mahan, J.R.; Allen, R.D. Stress tolerance in transgenic tobacco seedlings that overexpress glutathione S-transferase/glutathione peroxidase. Plant Cell Physiol. 2000, 41, 1229-1234. [CrossRef]

188. Zinn, K.E.; Tunc-Ozdemir, M.; Harper, J.F. Temperature stress and plant sexual reproduction: Uncovering the weakest links. J. Exp. Bot. 2010, 61, 1959-1968. [CrossRef] [PubMed]

189. DiPaola, J.; Beard, J. Physiological effects of temperature stress. Turfgrass 1992, 32, 231-267.

190. Shah, F.; Huang, J.; Cui, K.; Nie, L.; Shah, T.; Chen, C.; Wang, K. Impact of high-temperature stress on rice plant and its traits related to tolerance. J. Agric. Sci. 2011, 149, 545-556. [CrossRef]

191. Qu, A.-L.; Ding, Y.-F.; Jiang, Q.; Zhu, C. Molecular mechanisms of the plant heat stress response. Biochem. Biophys. Res. Commun. 2013, 432, 203-207. [CrossRef]

192. Beck, E.H.; Heim, R.; Hansen, J. Plant resistance to cold stress: Mechanisms and environmental signals triggering frost hardening and dehardening. J. Biosci. 2004, 29, 449-459. [CrossRef] 
193. Adam, S.; Murthy, S. Effect of cold stress on photosynthesis of plants and possible protection mechanisms. In Approaches to Plant Stress and Their Management; Springer: Berlin/Heidelberg, Germany, 2014; pp. 219-226.

194. Larkindale, J.; Vierling, E. Core genome responses involved in acclimation to high temperature. Plant Physiol. 2008, 146, 748-761. [CrossRef]

195. Sedaghatmehr, M.; Mueller-Roeber, B.; Balazadeh, S. The plastid metalloprotease FtsH6 and small heat shock protein HSP21 jointly regulate thermomemory in Arabidopsis. Nat. Commun. 2016, 7, 12439. [CrossRef]

196. Davletova, S.; Schlauch, K.; Coutu, J.; Mittler, R. The zinc-finger protein Zat12 plays a central role in reactive oxygen and abiotic stress signaling in Arabidopsis. Plant Physiol. 2005, 139, 847-856. [CrossRef] [PubMed]

197. Turóczy, Z.; Kis, P.; Török, K.; Cserháti, M.; Lendvai, A.; Dudits, D.; Horváth, G.V. Overproduction of a rice aldo-keto reductase increases oxidative and heat stress tolerance by malondialdehyde and methylglyoxal detoxification. Plant Mol. Biol. 2011, 75 , 399-412. [CrossRef] [PubMed]

198. Jung, K.-H.; Cao, P.; Seo, Y.-S.; Dardick, C.; Ronald, P.C. The Rice Kinase Phylogenomics Database: A guide for systematic analysis of the rice kinase super-family. Trends Plant Sci. 2010, 15, 595-599. [CrossRef] [PubMed]

199. Vazquez-Hernandez, M.; Romero, I.; Escribano, M.I.; Merodio, C.; Sanchez-Ballesta, M.T. Deciphering the role of CBF/DREB transcription factors and dehydrins in maintaining the quality of table grapes cv. autumn royal treated with high $\mathrm{CO}_{2}$ levels and stored at 0 C. Front. Plant Sci. 2017, 8, 1591. [CrossRef] [PubMed]

200. Robison, J.D.; Yamasaki, Y.; Randall, S.K. The ethylene signaling pathway negatively impacts CBF/DREB-regulated cold response in soybean (Glycine max). Front. Plant Sci. 2019, 10, 121. [CrossRef] [PubMed]

201. Shi, Y.; Ding, Y.; Yang, S. Molecular regulation of CBF signaling in cold acclimation. Trends Plant Sci. 2018, 23, 623-637. [CrossRef]

202. Chinnusamy, V.; Ohta, M.; Kanrar, S.; Lee, B.-h.; Hong, X.; Agarwal, M.; Zhu, J.-K. ICE1: A regulator of cold-induced transcriptome and freezing tolerance in Arabidopsis. Genes Dev. 2003, 17, 1043-1054. [CrossRef]

203. Fan, Z.-Q.; Chen, J.-Y.; Kuang, J.-F.; Lu, W.-J.; Shan, W. The banana fruit SINA ubiquitin ligase MaSINA1 regulates the stability of MaICE1 to be negatively involved in cold stress response. Front. Plant Sci. 2017, 8, 995. [CrossRef]

204. Amm, I.; Sommer, T.; Wolf, D.H. Protein quality control and elimination of protein waste: The role of the ubiquitin-proteasome system. Biochim. Biophys. Acta (BBA) Mol. Cell Res. 2014, 1843, 182-196. [CrossRef]

205. Goldberg, A.L. Protein degradation and protection against misfolded or damaged proteins. Nature 2003, 426, 895-899. [CrossRef]

206. Tamás, M.J.; Sharma, S.K.; Ibstedt, S.; Jacobson, T.; Christen, P. Heavy metals and metalloids as a cause for protein misfolding and aggregation. Biomolecules 2014, 4, 252-267. [CrossRef] [PubMed]

207. Farid, M.; Shakoor, M.B.; Ehsan, S.; Ali, S.; Zubair, M.; Hanif, M. Morphological, physiological and biochemical responses of different plant species to Cd stress. Int. J. Chem. Biochem. Sci. 2013, 3, 53-60.

208. Bielen, A.; Remans, T.; Vangronsveld, J.; Cuypers, A. The influence of metal stress on the availability and redox state of ascorbate, and possible interference with its cellular functions. Int. J. Mol. Sci. 2013, 14, 6382-6413. [CrossRef]

209. Emamverdian, A.; Ding, Y.; Mokhberdoran, F.; Xie, Y. Heavy metal stress and some mechanisms of plant defense response. Sci. World J. 2015, 2015, 756120. [CrossRef] [PubMed]

210. Schutzendubel, A.; Polle, A. Plant responses to abiotic stresses: Heavy metal-induced oxidative stress and protection by mycorrhization. J. Exp. Bot. 2002, 53, 1351-1365. [CrossRef] [PubMed]

211. Rascio, N.; Navari-Izzo, F. Heavy metal hyperaccumulating plants: How and why do they do it? And what makes them so interesting? Plant Sci. 2011, 180, 169-181. [CrossRef] [PubMed]

212. Xiang, M.; Li, Y.; Yang, J.; Lei, K.; Li, Y.; Li, F.; Zheng, D.; Fang, X.; Cao, Y. Heavy metal contamination risk assessment and correlation analysis of heavy metal contents in soil and crops. Environ. Pollut. 2021, 278, 116911. [CrossRef]

213. Kaur, R.; Das, S.; Bansal, S.; Singh, G.; Sardar, S.; Dhar, H.; Ram, H. Heavy metal stress in rice: Uptake, transport, signaling, and tolerance mechanisms. Physiol. Plant. 2021, 173, 430-448. [CrossRef]

214. Taiz, L. The plant vacuole. J. Exp. Biol. 1992, 172, 113-122. [CrossRef]

215. Li, G.-W.; Peng, Y.-H.; Yu, X.; Zhang, M.-H.; Cai, W.-M.; Sun, W.-N.; Su, W.-A. Transport functions and expression analysis of vacuolar membrane aquaporins in response to various stresses in rice. J. Plant Physiol. 2008, 165, 1879-1888. [CrossRef]

216. Meharg, A.A.; Jardine, L. Arsenite transport into paddy rice (Oryza sativa) roots. New Phytol. 2003, 157, 39-44. [CrossRef] [PubMed]

217. Vert, G.; Grotz, N.; Dédaldéchamp, F.; Gaymard, F.; Guerinot, M.L.; Briat, J.-F.; Curie, C. IRT1, an Arabidopsis transporter essential for iron uptake from the soil and for plant growth. Plant Cell 2002, 14, 1223-1233. [CrossRef] [PubMed]

218. Fan, S.K.; Fang, X.Z.; Guan, M.Y.; Ye, Y.Q.; Lin, X.Y.; Du, S.T.; Jin, C.W. Exogenous abscisic acid application decreases cadmium accumulation in Arabidopsis plants, which is associated with the inhibition of IRT1-mediated cadmium uptake. Front. Plant Sci. 2014, 5, 721. [CrossRef]

219. Han, M.; Park, Y.; Kim, I.; Kim, E.-H.; Yu, T.-K.; Rhee, S.; Suh, J.-Y. Structural basis for the auxin-induced transcriptional regulation by Aux/IAA17. Proc. Natl. Acad. Sci. USA 2014, 111, 18613-18618. [CrossRef] [PubMed]

220. Guo, J.; Qin, S.; Rengel, Z.; Gao, W.; Nie, Z.; Liu, H.; Li, C.; Zhao, P. Cadmium stress increases antioxidant enzyme activities and decreases endogenous hormone concentrations more in Cd-tolerant than Cd-sensitive wheat varieties. Ecotoxicol. Environ. Saf. 2019, 172, 380-387. [CrossRef] [PubMed]

221. Yuan, H.M.; Huang, X. Inhibition of root meristem growth by cadmium involves nitric oxide-mediated repression of auxin accumulation and signalling in Arabidopsis. Plant Cell Environ. 2016, 39, 120-135. [CrossRef] 
222. Corguinha, A.P.B.; de Souza, G.A.; Gonçalves, V.C.; de Andrade Carvalho, C.; de Lima, W.E.A.; Martins, F.A.D.; Yamanaka, C.H.; Francisco, E.A.B.; Guilherme, L.R.G. Assessing arsenic, cadmium, and lead contents in major crops in Brazil for food safety purposes. J. Food Compos. Anal. 2015, 37, 143-150. [CrossRef]

223. Khan, M.U.; Malik, R.N.; Muhammad, S. Human health risk from heavy metal via food crops consumption with wastewater irrigation practices in Pakistan. Chemosphere 2013, 93, 2230-2238. [CrossRef]

224. Struk, S.; Jacobs, A.; Sánchez Martín-Fontecha, E.; Gevaert, K.; Cubas, P.; Goormachtig, S. Exploring the protein-protein interaction landscape in plants. Plant Cell Environ. 2019, 42, 387-409. [CrossRef] 